\title{
Quaternary sediment dynamics in the Belgica mound province, Porcupine Seabight: ice-rafting events and contour current processes
}

Received: 31 December 2003 / Accepted: 2 March 2006/Published online: 22 April 2006

(c) Springer-Verlag 2006

\begin{abstract}
The Belgica cold-water coral banks on the eastern slope of the Porcupine Seabight are closely associated with bottom currents. In order to better understand the local temporal and spatial characteristics, as well as the palaeoclimatologic influences, a $26 \mathrm{~m}$ long core, taken on a small contourite drift, was studied. This sediment record of approximately $100 \mathrm{ka} \mathrm{BP}$ reveals new insights into the regional glacial and sedimentary processes, which are intrinsically linked to several geological, climatological, biological and hydrodynamic variables. The glacial sequences in the core contain six ice-rafting events (IRE). They are comparable with the North Atlantic Heinrich Events, although their characteristics show dominant influences from the proximal British-Irish Ice Sheet (BIIS). These IRE have a low magnetic susceptibility and are deposited during two or three ice-rafting pulses. The record of ice-rafting suggests a millennial-scaled BIIS destabilisation and confirms the start of a final retreat about $25 \mathrm{ka}$
\end{abstract}

D. Van Rooij $(\bowtie) \cdot$ J.-P. Henriet

Renard Centre of Marine Geology (RCMG),

Ghent University, Krijgslaan 281 S8,

9000 Gent, Belgium

E-mail: david.vanrooij@ugent.be

Tel: + 32-9-2644583

Fax: + 32-9-2644967

D. Blamart · D. Van Rooij

Laboratoire des Sciences de Climat et de l'Environnement (LSCE),

Laboratoire mixte CNRS/CEA, Bâtiment 12,

avenue de la Terrasse, 91198 Gif-sur-Yvette, France

T. Richter

Royal Netherlands Institute for Sea Research (NIOZ),

59, 1790 AB Den Burg, Texel, The Netherlands

A. Wheeler

Department of Geology and Environmental Research Institute, University College Cork, Cork, Ireland

M. Kozachenko

Coastal and Marine Resources Centre,

University College Cork,

Cork, Ireland ago. Additionally, the glacial sequence corresponds to a muddy contourite, influenced by bottom-current strength variations during interstadials, possibly triggered by sporadic reintroductions of Mediterranean Outflow Water in a glacial North Atlantic Ocean. The interglacial sequence features an 11-m thick deep-water massive sand unit, probably deposited under a highenergy bottom-current regime.

Keywords Contourite Ice-rafting event · British-Irish ice sheet · Porcupine Basin $\cdot$ Coral banks

\section{Introduction}

The north-eastern margin of the Porcupine Seabight is characterised by the presence of numerous giant coral banks (De Mol et al. 2002, 2005; Huvenne et al. 2002, 2005; Foubert et al. 2005; Wheeler et al., this volume) and sediment drifts (Van Rooij et al. 2003) (Fig. 1). The coral banks are prominent features on the margin and cause deflection and acceleration of benthic currents (Wheeler et al. 2005). Previous studies show that the local morphologic and hydrographic characteristics of this environment make this site attractive for cold-water coral settlement and growth, implying that benthic currents are also intrinsic to the growth of the mounds (De Mol et al. 2002; Huvenne et al. 2002; Wheeler et al., this volume). The present shape of the seafloor is derived from several geological, biological, oceanographic and climatologic events during the Late Cenozoic. De Mol et al. (2002) and Van Rooij et al. (2003) attributed the south-north alignment of these coral banks, as visible on multibeam imagery (Beyer et al. 2003), to the presence of eroded ridges of an acoustically transparent unit of probable Miocene origin, on which juvenile coral settling was favoured. One of the major goals of the EC FP5 ECOMOUND and GEOMOUND programmes was to provide clues involving the nature of the relationship between the coral banks and the surrounding hydrodynamic environment. 


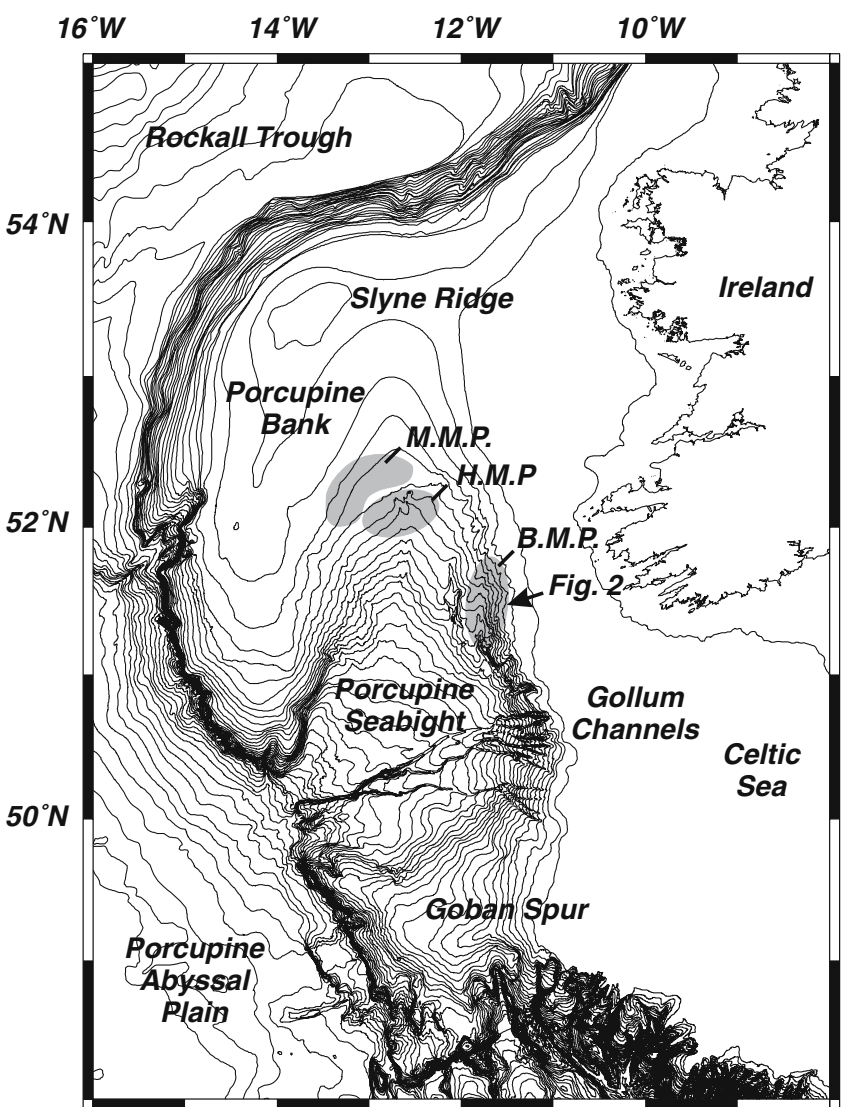

Fig. 1 Location map of the Porcupine Seabight with main morphologic features and inset of the study area (Gebco contour lines every $100 \mathrm{~m}) . B M P$ Belgica Mound Province, HMP Hovland Mound Province, MMP Magellan Mound Province

Various authors consider sediment drifts as ideal targets for palaeoceanographic and palaeoclimatologic studies (McCave et al. 1995; Rebesco and Stow 2001). Van Rooij et al. (2003) also recognised a close relationship between the positions of the Belgica mounds and the presence and shape of the surrounding sediment drift bodies. A better understanding of the functioning of these sediment drifts would also imply a better view on their relationship with the coral banks. However, within the Porcupine Seabight, very little is known about the regional Quaternary palaeoceanography. This basin is located in an ideal proximal position for the study of the evolution and the variability of the Irish component of the British-Irish Ice Sheet (BIIS). At present, available information is largely based on on-land work research (Bowen et al. 2002) and from work in surrounding basins (Scourse et al. 2000; Richter et al. 2001; Auffret et al. 2002; Knutz et al. 2002).

In this paper, we will focus on one specific site (core MD99-2327) in the Belgica mound province in order to find out (1) how the functioning of the BIIS was recorded in the sedimentary record and (2) the nature, characteristics and variability of the sediment drift body dynamics.

\section{Geological and hydrographic framework}

The Porcupine Seabight can be considered as an amphitheatre-shaped embayment in the NE Atlantic margin (Fig. 1). It is enclosed by four shallow platforms, consisting of metamorphic Precambrian and Palaeozoic rocks: the Porcupine Bank on the western side, Slyne Ridge in the north, the Irish Mainland Shelf in the east and the terraced Goban Spur in the south. The only opening towards the Porcupine Abyssal Plain lies between the Porcupine Bank and Goban Spur to the south-west. The underlying structure of the Porcupine Basin is a Middle to Late Jurassic failed rift of the protoNorth Atlantic. During the Cenozoic post-rift period, which is mainly characterised by thermal subsidence with approximately $10 \mathrm{~km}$ of sediment has been deposited in the centre of the basin (Moore and Shannon 1992; Shannon et al., this volume). Probably since the Pliocene, cold-water corals started settling in three different sites in the Porcupine Seabight at intermediate water depths between 500 and 1,000 m: the large Hovland mounds in the north (De Mol et al. 2002; Dorschel et al. 2005, this volume; Rüggeberg et al. 2005, this volume), the buried and numerous Magellan mounds further to the north-west (Huvenne et al., this volume) and the Belgica mounds on the eastern part of the slope (Fig. 1). More detailed information about the geological aspect, internal structure and spatial distribution of the mounds are discussed by De Mol et al. (2002). The recent basin sedimentation is pelagic to hemipelagic, although (probably reworked) foraminiferal sands can be found on the upper slope of the eastern continental margin (Rice et al. 1991). Within the three mound provinces, evidence is found of bottom-current-controlled sedimentation. However, the intensity of this process is greater in the Belgica mound province than with respect to the other two mound provinces (De Mol et al. 2002; Huvenne et al. 2002; Van Rooij et al. 2003). Numerous bedforms indicative of strong bottom currents and active sediment transport were observed on side-scan sonar imagery. These include sediment waves, gravel ridges, barchan dunes and seabed striations (Wheeler et al. 2005, this volume). The main sediment supply zone is probably located on the Irish and Celtic shelves, while the input from within the Porcupine Bank seems to be rather limited (Rice et al. 1991).

The present-day hydrographic setting, which has been extensively reviewed by White (this volume), features Eastern North Atlantic Water (ENAW) to a depth of about $600 \mathrm{~m}$ where it overlies Mediterranean Outflow Water (MOW). The flow of ENAW seems to be partly carried by the Shelf Edge Current, which flows northwards long the NE Atlantic margin (Pingree and Le Cann 1989; Huthnance 1995). The core of the MOW within the Porcupine Seabight is characterised by a salinity maximum between 800 and $1,100 \mathrm{~m}$. At the Belgica mound province, the water mass characteristics are thus more readily influenced by MOW. This water 
mass is underlain at $1,700 \mathrm{~m}$ by the North East Atlantic Deep Water and the Labrador Sea Water. At 1,900 m depth, the influence of Norwegian Sea Water is detected (Hargreaves 1984; Rice et al. 1991). Along the eastern margin, which is affected by a cyclonically flowing boundary current, currents are predicted to be strongest at mid-slope $(500-600 \mathrm{~m})$. These bottom currents are strongly steered by bottom topography. Mean flows from the predominant cyclonic circulation are in between 2 and $5 \mathrm{~cm} \mathrm{~s}^{-1}$, up to $10 \mathrm{~cm} \mathrm{~s}^{-1}$ within the Belgica mounds (White, this volume). Additionally, Rice et al. (1990) have suggested the condition for reflecting internal waves is met at a depth between 900 and $1,000 \mathrm{~m}$. These resulting enhanced currents are also influenced by a seasonal and diurnal periodicity (White, this volume). Within the vicinity of the mounds, currents are expected to be greater than $15 \mathrm{~cm} \mathrm{~s}^{-1}$ although maximum speeds of $70 \mathrm{~cm} \mathrm{~s}^{-1}$ are recorded from the summit of the Galway Mound, Belgica mound province (Roberts et al. 2005) and Wheeler et al. (2005) infers current speeds of up to $60 \mathrm{~cm} \mathrm{~s}^{-1}$ in off-mound areas within the province. This complex system of enhanced currents has also been predicted by hydrodynamic modelling (New et al. 2001).

\section{Materials and methods}

\section{Acoustic imagery}

The presented multibeam data (Fig. 2) were collected by means of a $15.5 \mathrm{kHz}$ Hydrosweep 2DS multibeam echosounder, during the ANTXVII/4 cruise of the R/V Polarstern (May-June 2000) and covers the entire
Belgica mound province (Beyer et al. 2003). The same area was also surveyed with a dual frequency GeoAcoustic (100 and $410 \mathrm{kHz})$ side-scan sonar in conjunction with a $3.5 \mathrm{kHz}$ sub-bottom profiler on board RRS Discovery in July and August 2000 (Wheeler et al. 2000, 2005). Side-scan sonar swath width was $600 \mathrm{~m}$ at $100 \mathrm{kHz}$ and $200 \mathrm{~m}$ at $410 \mathrm{kHz}$. Acquired digital sidescan sonar data was processed at the Southampton Oceanographic Centre using the PRISM sonar software system (Le Bas and Hühnerbach 1999). The sub-bottom profiler data was unprocessed and recorded on thermographic paper.

The RCMG very high-resolution seismic profiles were obtained during several campaigns of $\mathrm{R} / \mathrm{V}$ Belgica from 1997 to 2001. The seismic signal was created with a SIG surface sparker source $(500 \mathrm{~J})$, resulting in a frequency between 200 and 3,000 Hz. The standard vertical resolution of this method is $0.5-1 \mathrm{~m}$. The acoustic penetration ranges from 400 to $800 \mathrm{~ms}$ two-way travel time. The data of all surveys were digitally recorded on an ELICS Delph 2-system with a sample rate of $4 \mathrm{kHz}$ and processed with Landmark PROMAX software on a SUN workstation. As a general work flow, the data processing involved a Butterworth bandpass filter $(250 \mathrm{~Hz}$ with a $24 \mathrm{db} /$ oct slope and $700 \mathrm{~Hz}$ with a $36 \mathrm{db} /$ oct slope), minimum phase spiking deconvolution, automatic gain control using a mean of $250 \mathrm{~ms}$ and a true amplitude recovery, where necessary.

\section{Sedimentology}

Two sedimentary cores have been studied, both lying on the same location at $651 \mathrm{~m}$ below sea level (Fig. 2a).

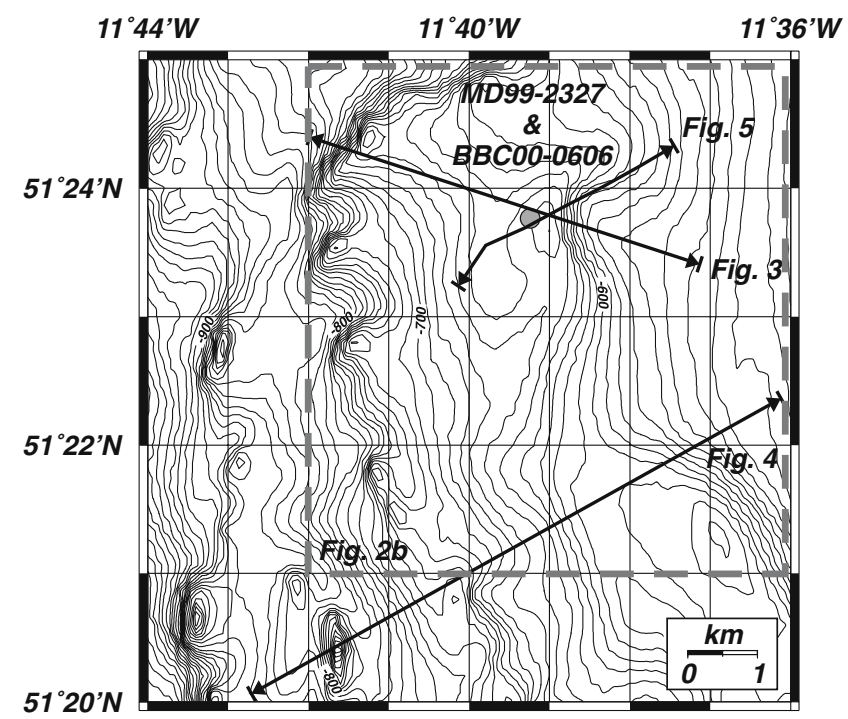

(a)

Fig. 2 a Multibeam bathymetry map illustrating the north-south alignment of the coral banks, with indication of the very highresolution RCMG sparker seismic profiles (Figs. 4, 5), the RRS

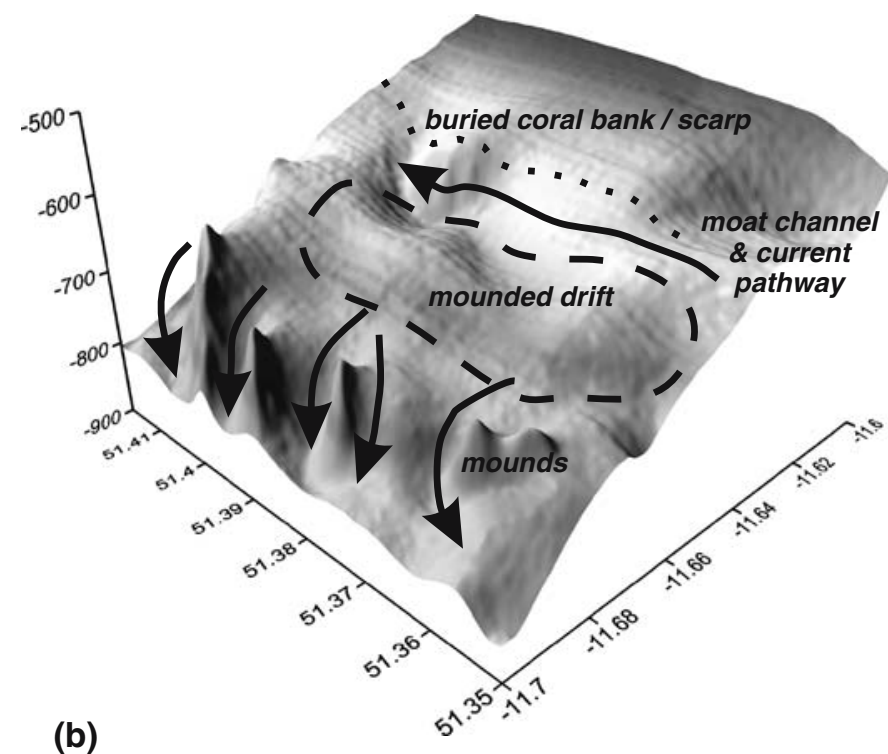

Discovery $2483.5 \mathrm{kHz}$ sub-bottom profiler line (Fig. 3) and core location. b Surface 3D map of the dashed area within (a), illustrating the main morphological elements 
Calypso core MD99-2327 (26.25 m) was taken during the IMAGES V cruise on board of R/V Marion Dufresne in 1999. Additionally, boxcore BBC00-0606 $(21 \mathrm{~cm})$ was taken during the Porcupine-Belgica 2000 campaign of $\mathrm{R} / \mathrm{V}$ Belgica in order to obtain the seabed surface sediment, which usually is missing using the Calypso core technique (Skinner and McCave 2003). Whole core, high-resolution sediment physical properties of MD992327 were obtained using the Geotek MultiSensor Track at a downcore resolution of $2 \mathrm{~cm}$. These measurements comprised GRAPE density $\left({ }^{137} \mathrm{Cs}\right.$ source) and magnetic susceptibility (MS) (Bartington loop sensor MS2B). Digital X-ray images were obtained from $1 \mathrm{~cm}$ thick core slabs with the SCOPIX system (Migeon et al. 1999). Major $(\mathrm{Ca}, \mathrm{Fe}, \mathrm{Ti}, \mathrm{K}$ and $\mathrm{Si}$ ) and minor ( $\mathrm{Mn}$ and $\mathrm{Sr}$ ) element composition were obtained by non-destructive XRF (X-ray fluorescence) logging with the CORTEX core scanner (Jansen et al. 1998). The XRF analysis will only be discussed in terms of selected results of $\mathrm{Ca}, \mathrm{Fe}$ and Si. Two intervals $(1,812-1,786$ and $1,651-1,510 \mathrm{~cm})$ were not analysed, because it was not possible to create the required smooth sediment surface. Results are presented as percentages of the total element counts.

Both cores were subject to subsampling for sedimentological analyses. MD99-2327 was sampled every $10 \mathrm{~cm}(20-30 \mathrm{~g})$, while BBC00-0606 was cut up in slabs of $1 \mathrm{~cm}(25-30 \mathrm{~g})$. These subsamples were dried on $60^{\circ} \mathrm{C}$ in order to calculate dry bulk density with Eqs. 1 and 2:

$P=1 /\left(\left(\left(\rho_{\mathrm{w}} / \rho_{\mathrm{g}}\right) \cdot((1-W) / W)\right)+1\right)$

$\rho_{\mathrm{d}}=\rho_{\mathrm{g}} \cdot(1-P)$

where $P$ is the porosity, $\rho_{\mathrm{w}}$ is the density of water $\left(1.024 \mathrm{~g} \mathrm{~cm}^{-3}\right), \quad \rho_{\mathrm{g}}$ is a hypothetic grain density $\left(2.65 \mathrm{~g} \mathrm{~cm}^{-3}\right), \rho_{\mathrm{d}}$ is the dry bulk density of the sample $\left(\mathrm{g} \mathrm{cm}^{-3}\right)$ and $W$ is the water content calculated from the difference in total sample weight before and after drying.

All subsamples were subject to particle size analysis using laser diffraction techniques with a Malvern Laser Particle Sizer (MasterSizer 2000). Before analysis, each subsample was dispersed in a $10 \%$ sodium polyphosphate solution made with distilled water and shaken for $24 \mathrm{~h}$ in order to achieve a perfect dispersion of all particles within the sample. The bulk particle size distributions were statistically analysed to produce mean, sorting and skewness. The sortable silt index (mean 10-63 $\mu \mathrm{m}$ ) from mud-dominated sediments was also derived as a proxy for bottom-current strength (McCave et al. 1995).

To provide a chronostratigraphic context, $5 \mathrm{~g}$ of the sediment sample was wet sieved with distilled water for all samples ( $3 \mathrm{~g}$ for the sandy part of core MD99-2327) in order to separate the fraction coarser than $150 \mu \mathrm{m}$. This fraction was dried again at $60^{\circ} \mathrm{C}$ and weighed. The weight percentage of the fraction $>150 \mu \mathrm{m}\left(F_{150}\right)$ is calculated with Eq. 3:

$F_{150}=\left(W_{F_{150}} \times 100\right) / W_{\mathrm{d}}$

where $W_{F_{150}}$ is the weight of the fraction $>150 \mu \mathrm{m}(\mathrm{g})$ and $W_{\mathrm{d}}$ is the weight of the dried sediment $(\mathrm{g})$. The $F_{150}$ was further split to approximately $500-1,000$ grains and counted for the abundance of planktonic foraminifers and various types of lithic grains. The obtained results are recalculated and presented as number of grains per $10 \mathrm{~g}$ of dry sediment.

Between 10 and 20 tests of Neogloboquadrina pachyderma s. (NPS) were picked from the size fraction between 150 and $250 \mu \mathrm{m}$ and were ultrasonically cleaned for stable isotope measurements $\left(\delta^{18} \mathrm{O}\right.$ and $\left.\delta^{13} \mathrm{C}\right)$ at the LSCE (Gif-sur-Yvette, France) in order to have a chronostratigraphic framework. The analyses were performed on a VG Optima mass spectrometer equipped with an automatic carbonate acidification device. The isotopic values are reported as per mil deviation $(\%)$ with respect to the international V-PDB standard. The uncertainties on the isotope measurements are 0.08 and $0.05 \%$ respectively for oxygen and carbon. AMS ${ }^{14} \mathrm{C}$ dates (NPS) were also obtained for two intervals in core MD99-2327. These analyses were also performed at the LSCE and have been corrected for a mean reservoir age of 400 years (Bard 1998).

Once a chronological framework has been established, bulk sediment accumulation rates $\mathrm{ARb}$ in $\mathrm{g} \mathrm{cm}^{-2} \mathrm{ka}^{-1}$ were calculated with Eq. 4:

$\mathrm{ARb}=\mathrm{LSR} \cdot \rho_{\mathrm{d}}$

where LSR is the linear sedimentation rate in $\mathrm{cm} \mathrm{ka}^{-1}$ and $\rho_{\mathrm{d}}$ is the dry bulk density of the sample $\left(\mathrm{g} \mathrm{cm}^{-3}\right)$.

\section{Morphologic and seismic stratigraphic framework}

The morphology of the study area is characterised by three approximately south-north elongated features (Fig. 2a, b). In the east, 4-5 mound clusters are observed, rising up to $100 \mathrm{~m}$ above the sea floor. Downslope of this mound alignment, the mounds are free from sediment cover (Figs. 2b, 3). In between individual clusters, the mounds are flanked by southwest oriented gullies. More to the west, yet another elongated mounded feature is observed with a relief of approximately 50-60 m above the sea floor, being $6 \mathrm{~km}$ length and $2 \mathrm{~km}$ width. The sub-bottom profiler record only shows slightly mounded, sub-parallel strata. This sediment body is limited at its eastern side by a (northsouth elongated) moat channel, which seems to be, on its turn, flanked by a buried coral bank (Figs. 2b, 3). Although this buried mound is relatively local (approximately $1.5 \mathrm{~km}$ diameter), this structure makes part of a north-south elongated flank. Figure 3 also reveals the presence of a seabed typified by rippled sands.

The regional seismic stratigraphic framework, previously discussed by Van Rooij et al. (2003), includes four units (U1-U4), separated by three regional discontinuities (RD1-RD3). All units prove to be influenced by bottom-currents action either during or after deposition (Figs. 4, 5). Buried sigmoidal deposits observed in the Early to Middle Miocene Unit U3 already suggested the 
Fig. 3 WNW-ESE-oriented $3.5 \mathrm{kHz}$ sub-bottom profiler line over the coring site MD992327 with inset of a $410-\mathrm{kHz}$ side-scan sonar image with sand waves (RRS Discovery 248)

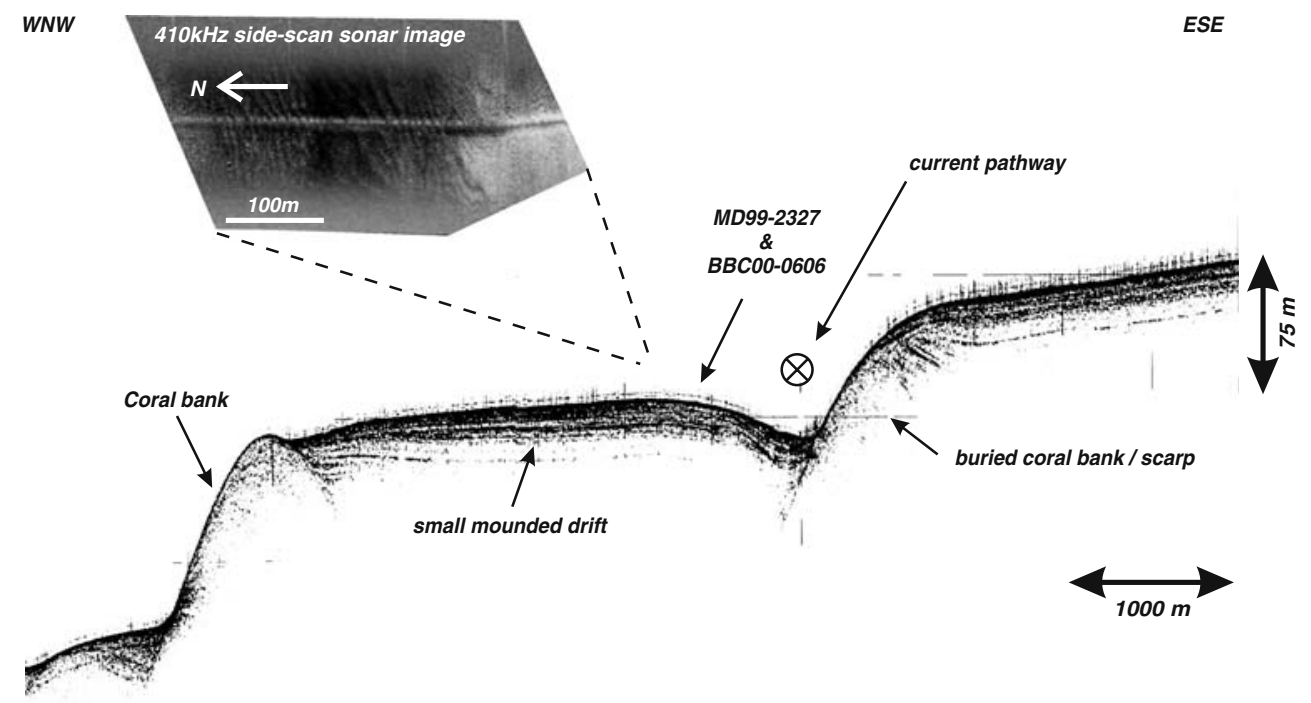

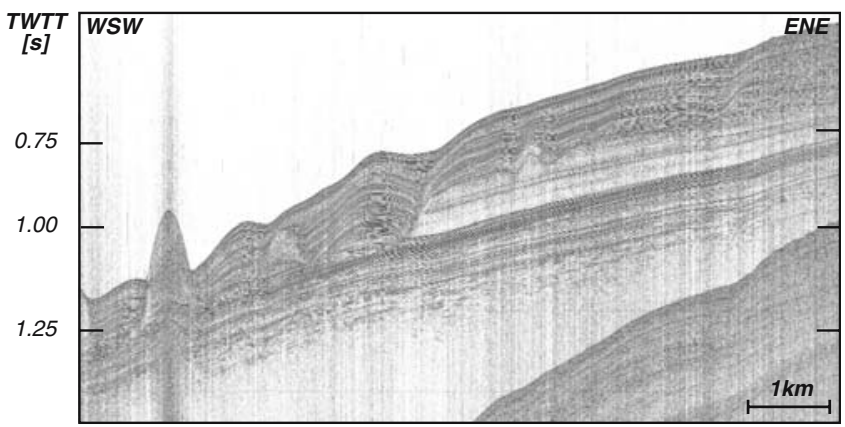

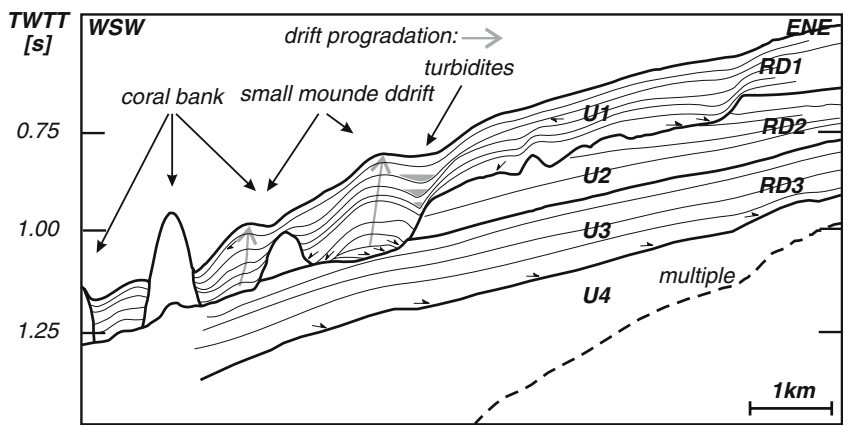

Fig. 4 WSW-ENE-oriented RCMG sparker profile P010521, located within the Belgica mound province, $4 \mathrm{~km}$ south of the coring site (Fig. 2a), illustrating the general seismic stratigraphic and morphologic setting

presence of vigorous bottom currents. This buried sediment drift is overlain with unit U2, clearly separated by a Mid-Miocene RD2 discontinuity (Van Rooij et al. 2003). Unit U2 is present on the entire upper slope and has an acoustically transparent character, although some sets of parallel high-amplitude reflectors are observed. Although little lithological information is known about this unit, the nature of the seismic facies suggests relatively homogeneous sediments. The set of internal reflectors could hint to possible post-depositional diagenesis or periods of non-deposition. Subsequently, a significant erosion event severely cut into these deposits. This RD1 discontinuity, with a probable Late Pliocene age (Van Rooij et al. 2003) left a very irregular terracelike palaeotopography. Deep incisions into unit U2 created large south-north oriented ridges, which are evident in the present-day topography. These ridges where colonised by framework-building corals at the initiation of coral bank growth (De Mol et al. 2002).

The recent most unit (U1) is characterised by continuous, high-frequency reflectors with varying amplitudes. In between the coral banks and the irregular palaeotopography created by the RD1 erosion, one can observe unit U1 has a mounded feature with a moderate ENE progradation. The oldest deposits seem to downlap towards the WSW and the ENE, which can be compared with mounded confined drifts as described by Carter and McCave (1994) and Reed et al. (1987). These small mounded drifts are shaped by the presence of the narrow passage formed by the steep palaeotopography and the mounds. Along these flanks, currents are expected to be intensified, thus preventing deposition at that location, shifting it towards the middle of this trough. This implies that the mounds should have reached a certain dimension that was significant enough to influence the current path. Furthermore, if this is true, the sediment drift deposition could only have started at that time, which invokes a period of non-sedimentation. Within this period, there would have been a limited supply of terrigenous material, but also enough nutrients and currents in order to stimulate mound growth.

The stratigraphy of the chosen coring site is presented in Fig. 5. The mound is still partly rooted to unit $\mathrm{U} 2$ and the extent of the RD1 erosion is nicely illustrated. The lower strata of this small mounded drift contain various small unconformities with evidence of very vigorous currents during the first stages of deposition (Van Rooij et al. 2003). Towards the flank of the mound, all strata are terminated by a moat channel. As well as in Fig. 4, 

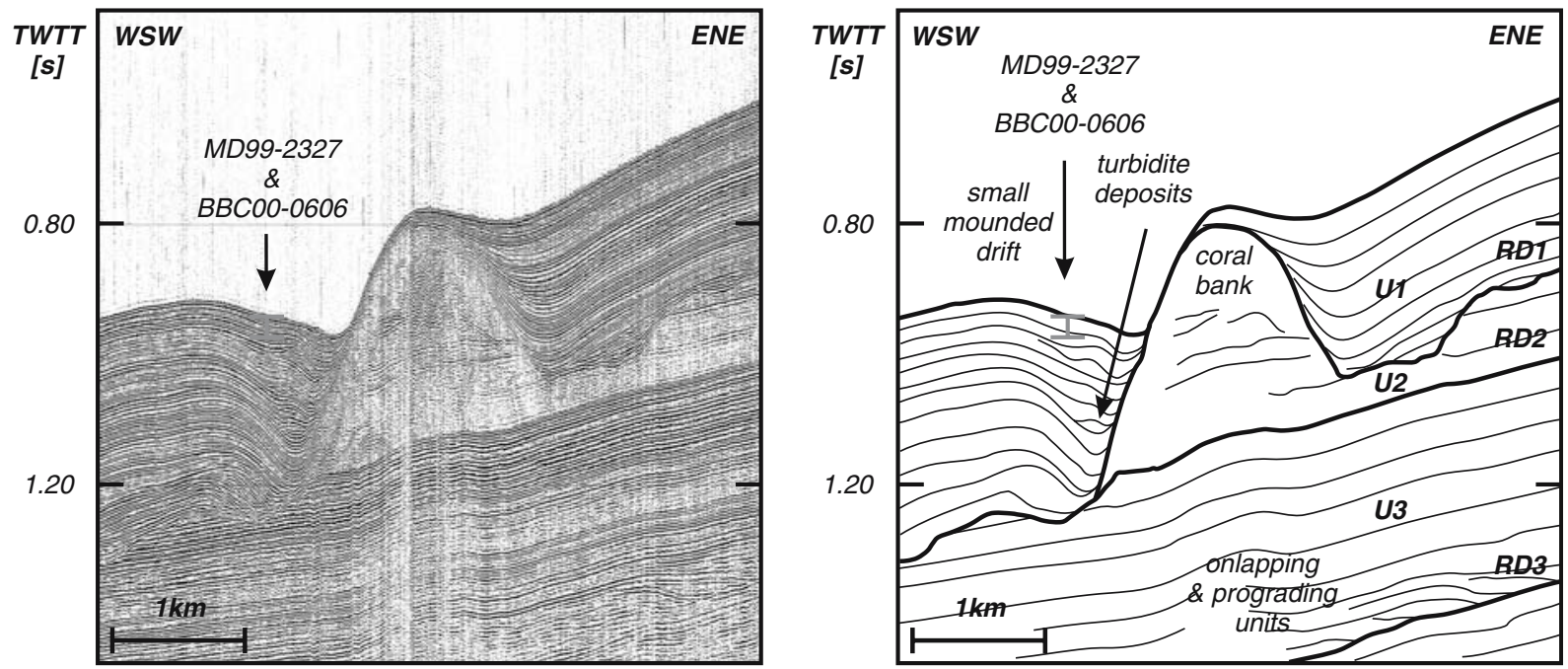

Fig. 5 WSW-ENE-oriented RCMG sparker profile P010517 through the coring site with interpretation of the site-specific stratigraphic features

these channels could be filled up by turbidite deposits, possibly fed by the gullies flanking the mounds (Fig. 4).

\section{Sedimentary characteristics}

\section{Lithology}

The sedimentary characteristics of the small mounded drift will be presented using two complementary datasets; boxcore BBC00-0606 $(21 \mathrm{~cm})$ and core MD99-2327 $(2,625 \mathrm{~cm})$, which for practical reasons are considered here as one integrated sequence. The lithology of this core site can be subdivided into three main units, in which two different lithofacies are dominant: a muddy facies and a sandy facies (Figs. 6, 7).

Unit I only is present in the upper $10 \mathrm{~cm}$ of $\mathrm{BBC} 00$ 0606 and consists of a soupy, coarse foraminiferal sand. Grain-size analysis shows moderately sorting with a high sand content (up to $94 \%$ ), which decreases towards the base of this unit to $23 \%$.

Unit II extends from $10 \mathrm{~cm}$ in BBC00-0606 and down to $1,425 \mathrm{~cm}$ in MD99-2327 and is featured as a homogeneous, olive grey silty clay with sulphide strikes at some intervals. From 1,193 to $1,233 \mathrm{~cm}$, muddy fine sand with occasional sulphide strikes and mollusc fragments is observed. The base of this unit $(1,233-1,425 \mathrm{~cm})$ is dominated by alternating layers of olive grey silty clay and muddy fine sand. The sediments are generally very poorly sorted, although sorting increases towards its base (Fig. 7). X-ray imagery reveals bioturbation (mottling, planolites, chondrites, mycelia) throughout, varying from faint structures to very heavy burrowing. Within the silty clay matrix, at several intervals distinct dropstones of several sizes are observed, as well as some subhorizontal layering (Fig. 8).
The transition between units II and III (1,500$2,625 \mathrm{~cm}$ ) coincides with a void interval, which occurred due to core stretching during sampling with the Calypso piston core. The sedimentary facies of unit III is similar to the olive grey foraminiferal fine to medium sand of unit I, although with subtle variations. From 1,500 to $1,760 \mathrm{~cm}$, two finer poorly sorted layers with a silt percentage up to $80 \%$ are observed (Fig. 7). These layers have sharp boundaries and are embedded in the typical sandy sediments. Within the latter sediments occasional shell fragments, lithic grains and dark minerals are described. The sorting of this interval is varies between very poorly to poorly sorted. From $1,760 \mathrm{~cm}$ onwards, the sediment is more homogeneous and contains medium olive sand with abundant foraminifera, occasional shell fragments and lithic grains. Although the sand is still poorly sorted, sorting is relatively better compared to the other units (Fig. 7). Here, the degree of bioturbation is difficult to assess where coarse-grained material is present within a fine-grained matrix. The lowest interval of the core, from 2,525 to $2,625 \mathrm{~cm}$, is represented by massive, dark greyish brown, muddy sand with abundant shell fragments and is again very poorly sorted (Fig. 7).

\section{Stratigraphic framework}

A tentative age model (yielding a sediment record of approximately $100 \mathrm{ka} \mathrm{BP)}$ was constructed, predominantly based on the palaeontological and geochemical characteristics of unit II. The grain-size composition and distribution of this unit (Fig. 7) shows a rather low-energy environment with only reworking in the finegrained sections, allowing this palaeoceanographic interpretation. The characteristics of unit III on the other hand suggest a high-energy environment, requiring 
Fig. 6 Physical properties, lithological content and chronostratigraphy of core MD99-2327 with: a relative abundance the planktonic foraminifera Neogloboquadrina pachyderma s., b $\delta^{18} \mathrm{O}$ stable isotopes (\% vs. PDB), c luminosity $\left(L^{*}\right)$, d dry bulk density $\left(\mathrm{g} \mathrm{cm}^{-3}\right)$, e fraction $>150 \mu \mathrm{m}$ (wt. $\%$ ) and $\mathbf{f}$ the magnetic susceptibility. The local ice-rafting events are indicated by the grey-shaded areas

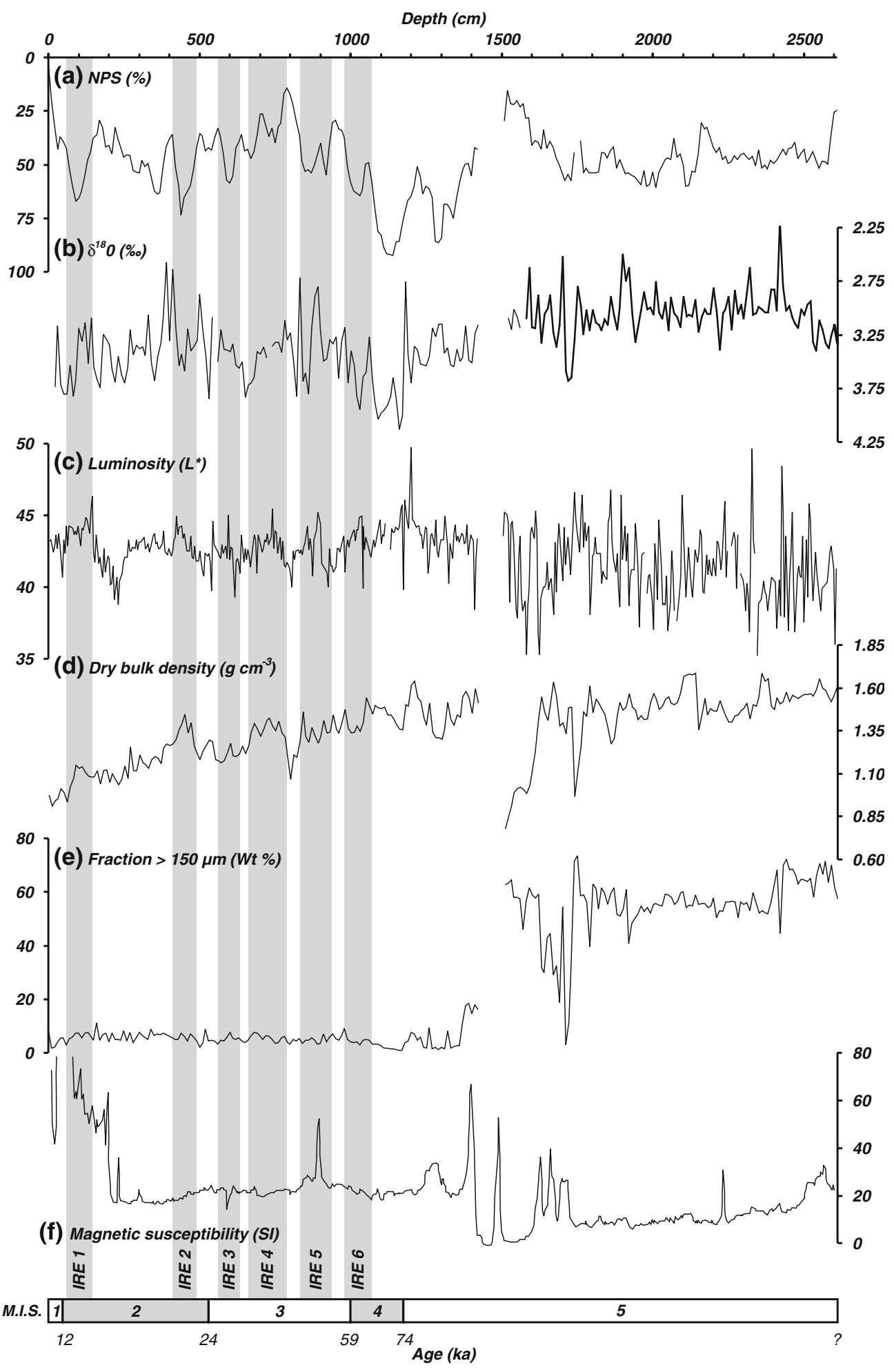

a more careful interpretation. As a first step, the variations in the measured parameters (Fig. 6) were linked to the main palaeoclimatologic events proposed by Martinson et al. (1987). Secondly, a more detailed stratigraphy was obtained in linking "local" ice-rafting events (IRE) with the occurrence of Heinrich layers (HL) on the Celtic margin (Auffret et al. 2002). Also two
AMS ${ }^{14} \mathrm{C}$ dates were obtained for the upper part of the core. All the obtained tie points are presented in Table 1.

\section{Main palaeoclimatologic events}

The upper $6 \mathrm{~cm}$ of boxcore $\mathrm{BBC} 00-0606$ contains a foraminiferal assemblage characteristic of the Holocene. 
Fig. 7 Sedimentary parameters of core MD99-2327; a mean $(\mu \mathrm{m})$, b sorting $(\mu \mathrm{m})$ and c skewness. Frequency distribution curves are inserted of d ice-rafting event (IRE1), illustrating the presence of icerafted debris on top of a current-sorted background sediment, e a peak current event (PCE3) in the muddy contourite and $\mathbf{f}$ the sandy contourite section with a coarse currentsorted mode and a subtle finegrained tail. The six IRE are indicated by the grey-shaded areas. The range of the PCE has also been indicated by arrowed lines

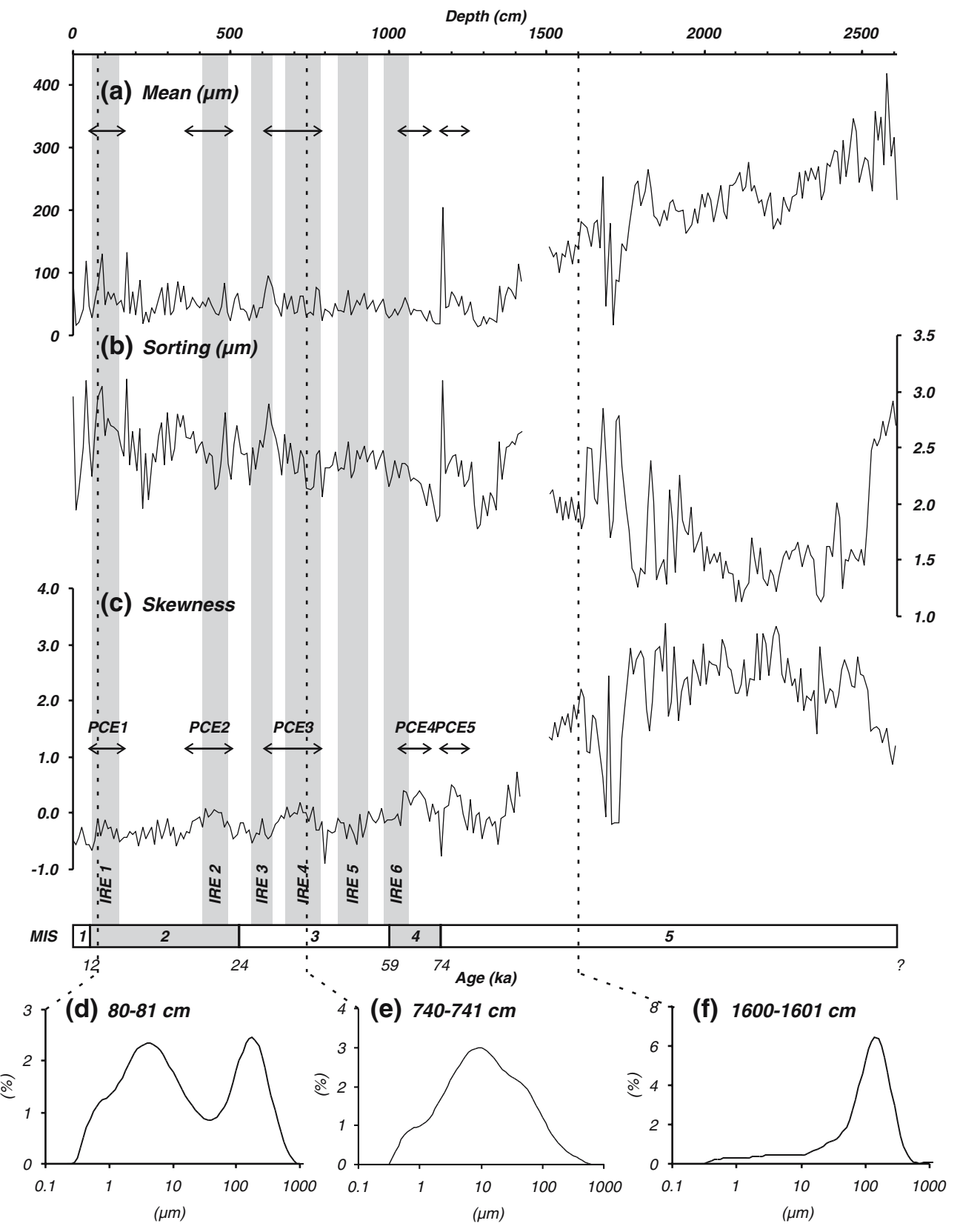

However, no really clear indication is present for attaining marine isotope stage 2 (MIS2) at the base of the boxcore. On the other hand, the top of core MD992327 does not display the light $\delta^{18} \mathrm{O}$ values and low percentages of NPS characteristic of the Holocene; although a sharp decrease in NPS marks the transition towards the Holocene optimum (Figs. 6, 9). In this level, Mertens (2002) observed reworked coccoliths due to the presence of higher benthic currents, started up at the beginning of the Holocene. Therefore the boundary between MIS1 and MIS2 is set at $50 \mathrm{~cm}$. Subsequently, MIS2 was located between 50 and $525 \mathrm{~cm}$, also based on NPS and further refined by the presence of IRE (see below). A general cooling trend in the $\delta^{18} \mathrm{O}$ and NPS starting from $1,000 \mathrm{~cm}$ downcore, suggests the transition from MIS3 to MIS4 is located at $1,000 \mathrm{~cm}$. MIS4 $(1,000-1,170 \mathrm{~cm})$ is characterised by a rather low amount of the fraction $>150 \mu \mathrm{m}$ and rather higher values of $\delta^{18} \mathrm{O}$ and NPS, which might be evidence of the build-up of an ice cap on the islands of Britain and Ireland.

From 1,170 to $2,525 \mathrm{~cm}$, the low values of $\delta^{18} \mathrm{O}$ and NPS are indicative of an interglacial period, most probably MIS5 (Fig. 6). Given the interglacial characteristics of this unit and its presumed high-energy environment, the exceptionally high amount of the coarse sand is difficult to interpret in terms of ice-rafting, but probably have a hydrodynamic origin, which will be discussed in a following section. Below $2,525 \mathrm{~cm} \delta^{18} \mathrm{O}$ values become heavier, indicating a slightly colder 
Fig. 8 SCOPIX X-ray visualisations of the six icerafting events (IRE) intervals; a IRE1, b IRE2, c IRE3, d IRE4a, e IRE4b and 4c, f IRE5 and $\mathbf{g}$ IRE6
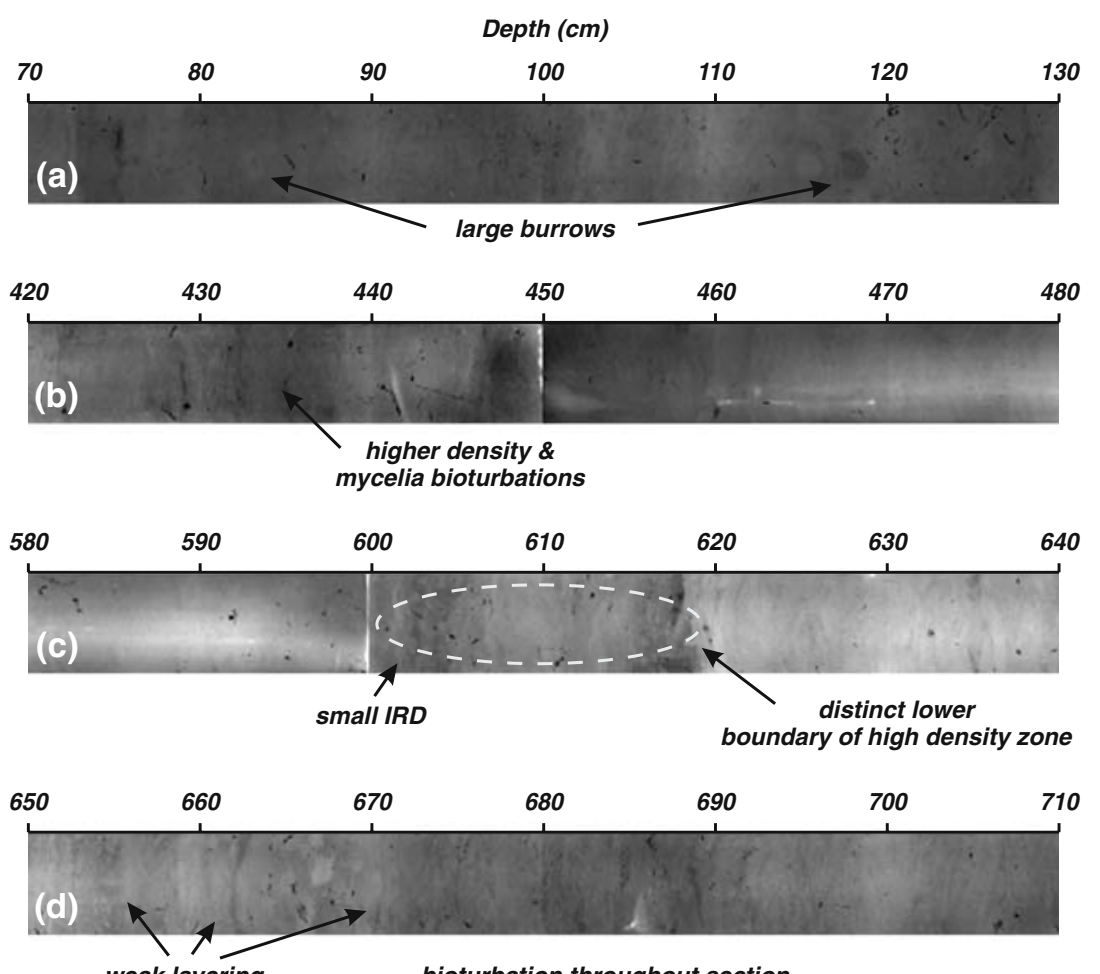
weak layering

bioturbation throughout section
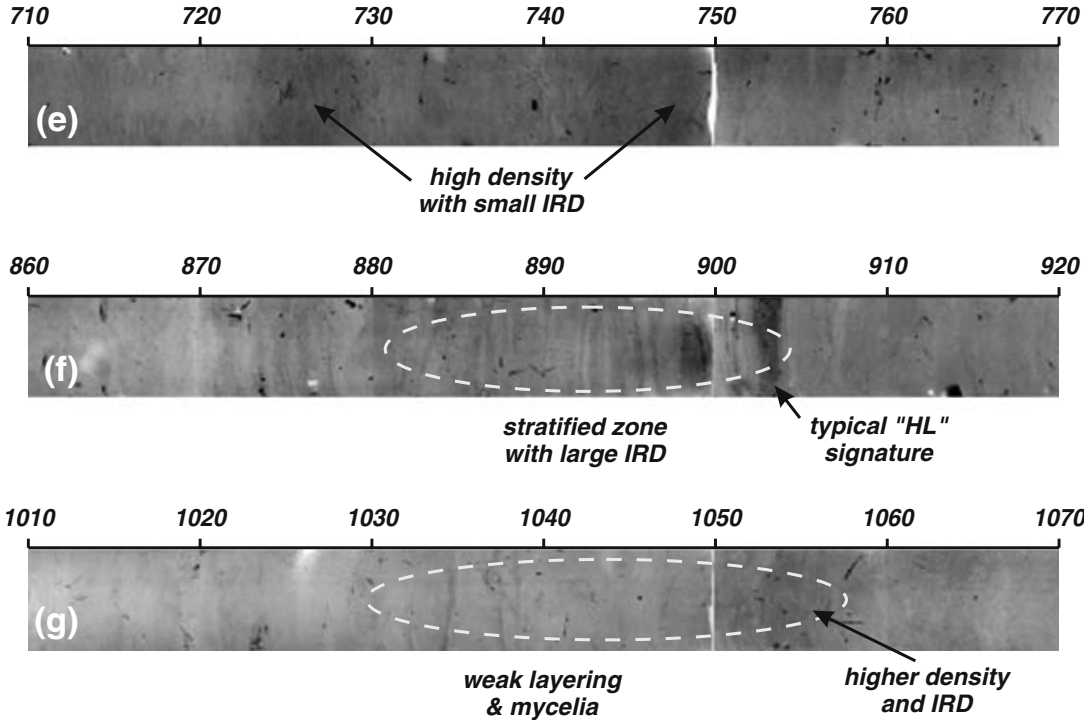

climate (Fig. 6). Therefore, we suggest the base of this core might be dated at approximately $100 \mathrm{ka} \mathrm{BP}$ (at about MIS5.3). Nevertheless, any age estimate of this unit III should be considered with great caution. Especially the large scatter in the oxygen isotope records could mean that (some of the) forams were reworked.

\section{Ice-rafting events}

Many studies within the NE Atlantic use the occurrence of $\mathrm{HL}$ as tie points for a relative chronostratigraphy. Especially within the Ruddiman belt, between 40 and $65^{\circ} \mathrm{N}$, all six HL commonly stand out in the record of ice-rafted debris (fraction $>150 \mu \mathrm{m}$ ) and allow successful relative dating of the last glacial period (Ruddiman 1977; Bond et al. 1992; Richter et al. 2001; Auffret et al. 2002; Knutz et al. 2002). Closer towards the European margins, the HL are intercalated between a series of local IRE and less pronounced (Elliot et al. 1998; Knutz et al. 2002). Moreover, frequent observations are made of European ice-sheet sourced IRE, which precede and post-date the well-known Heinrich Events (Snoeckx et al. 1999; Scourse et al. 2000; Grousset et al. 2001). Given the location of the area under study in this paper (Fig. 1), the local ice-rafting 
Table 1 Tie points of the tentative chronostratigraphic framework of core MD99-2327

\begin{tabular}{lllll}
\hline Depth (cm) & $\begin{array}{l}\text { Corrected }{ }^{14} \mathrm{C} \\
\text { age }(\mathrm{ka} \mathrm{BP})\end{array}$ & $\begin{array}{l}\text { Sedimentation } \\
\text { rate }\left(\mathrm{cm} \mathrm{ka}^{-1}\right)\end{array}$ & Core event & Data origin \\
\hline 0 & 10.00 & & & \\
50 & 12.00 & 25.00 & MIS1/2 & Martinson et al. (1987) \\
90 & $15.19 \pm 130 \mathrm{a}$ & 12.54 & IRE1 & AMS ${ }^{14}$ C (LSCE) \\
440 & $17.38 \pm 140 \mathrm{a}$ & 159.82 & IRE2 & AMS ${ }^{14}$ C (LSCE) \\
525 & 24.10 & 12.65 & MIS2/3 & Martinson et al. (1987) \\
600 & 26.60 & 30.00 & IRE3 & HL3 (Auffret et al. 2002) \\
730 & 34.20 & 17.11 & IRE4 & HL4 (Auffret et al. 2002) \\
900 & 45.50 & 15.04 & IRE5 & HL5 (Auffret et al. 2002) \\
1,000 & 58.96 & 7.43 & MIS3/4 & Martinson et al. (1987) \\
1,030 & 62.00 & 9.87 & IRE6 & HL6 (Auffret et al. 2002) \\
1,170 & 73.90 & 11.76 & MIS4/5 & Martinson et al. (1987) \\
\hline
\end{tabular}

history will be influenced much more by ice-rafted debris from a British/Irish source rather than a Laurentide one. For this reason, the recognition and interpretation of the IRE presented in this paper is not obvious and requires an amendment to the ice-rafted debris deposition story in comparison with the standard Heinrich Events chronology.

Diagnostic parameters of an IRE Five main parameters were used to identify IRE: foraminifers, $\delta^{18} \mathrm{O}$ stable isotopes, density (and radiographies), the nature of the ice-rafted debris and the Ca content (XRF and reflectance). However, one of the most diagnostic parameters for the recognition of HL, the MS fails to identify the IRE. Here, these five diagnostic characteristics are respectively presented and discussed with respect to the recognition of $\mathrm{HL}$.

Regardless of the presence of a proximal ice sheet, the reaction of planktonic foraminifers will remain the same during any IRE. During cold periods, the abundance of the entire assemblage will decrease, whereas the percentage of NPS will increase and the $\delta^{18} \mathrm{O}$ isotope signature will show lighter values, suggesting meltwater pulses (Bond et al. 1992; Elliot et al. 1998; Grousset et al. 2001). However, due to multiple meltwater events and the frequent ice volume changes from the nearby BIIS, the $\delta^{18} \mathrm{O}$ isotope values should not be used unambiguously.

Auffret et al. (1996), Chi and Mienert (1996) and Moros et al. (2002) have shown a positive relationship between the amount of ice-rafted debris in marine sediments and the dry bulk density. This can be attributed to (1) lower porosities in these poorly sorted deposits (Moros et al. 2002), (2) possibly to higher grain densities and (3) diagenetic calcite precipitation (Kassens and Sarnthein 1989; Auffret et al. 1996). Bond et al. (1992) also recognised this correlation using X-ray imagery, where they can be observed as dark, fairly homogenous levels (Fig. 8). In the studied core, almost all increases in dry bulk density were correlated with higher percentages of NPS, except for IRE3. Therefore, this parameter remains the main tool to detect HL and to characterise IRE (Fig. 9).

In contrast with many other NE Atlantic studies, the fraction $>150 \mu \mathrm{m}\left(F_{150}\right)$ only (Fig. 9) does not allow easy identification of singular HL or equivalent IRE. The amount of ice-rafted grains is fairly elevated (between 5 and $10 \%$ ) and highly fluctuating. However, combined with other diagnostic parameters, single IRE can be recognised. Some of these (i.e. IRE3 and IRE4) show a threefold structure (Fig. 9). Mineralogical analyses of the ice-rafted grains indicate the presence of three main lithic grain types; predominantly transparent quartz grains, rock fragments and discrete feldspars. These may have originated from Devonian and Carboniferous (Silesian) sandstones from southern Ireland (Holland 2001). The number of observed detrital carbonates and red-stained quartz, which are marker for LIS-sourced grains (Bond and Lotti 1995), was limited. A similar composition of the ice-rafted fraction was also described in cores located north of Ireland (Knutz et al. 2001).

Figure 9 shows an inverse relationship with NPS percentages and XRF Ca measurements. The elevated XRF Ca values in the interglacial MIS5 reflect enhanced biogenic carbonate productivity coinciding with warmer surface water temperatures (Fig. 10). In the glacial part (above 1,200 cm), however, this relationship starts to break down. The two uppermost Ca maxima (450 and $100 \mathrm{~cm}$ ) coincide with maxima of NPS indicating surface water cooling (Fig. 9). All this suggests elevated Ca values in this part of the core implying a relatively higher amount of detrital carbonate. A higher $\mathrm{Ca}$ content in IRE might relate to a higher amount of terrigenous detrital carbonate, coming from either from the LIS or from outcrops of Palaeozoic carbonates in Ireland. As a consequence, a higher amount of light-coloured grains as quartz and detrital carbonate might show up as a lighter facies within the luminosity record (Fig. 6). Since the HL in the Ruddiman belt are characterised by darker sediment colours (Grousset et al. 1993, 2001), the atypical XRF Ca and brighter luminosity records are supporting the idea of dominantly locally derived ice-rafted debris.

Traditionally, the most successful method to detect $\mathrm{HL}$ is the use of MS. Only Laurentide material carries a strong magnetic signal, explaining why HL3 and 6, which were attributed a more Icelandic-Fennoscandic origin, do not show up well in the MS record (Grousset et al. 1993; Thouveny et al. 1994; Snoeckx et al. 1999). 


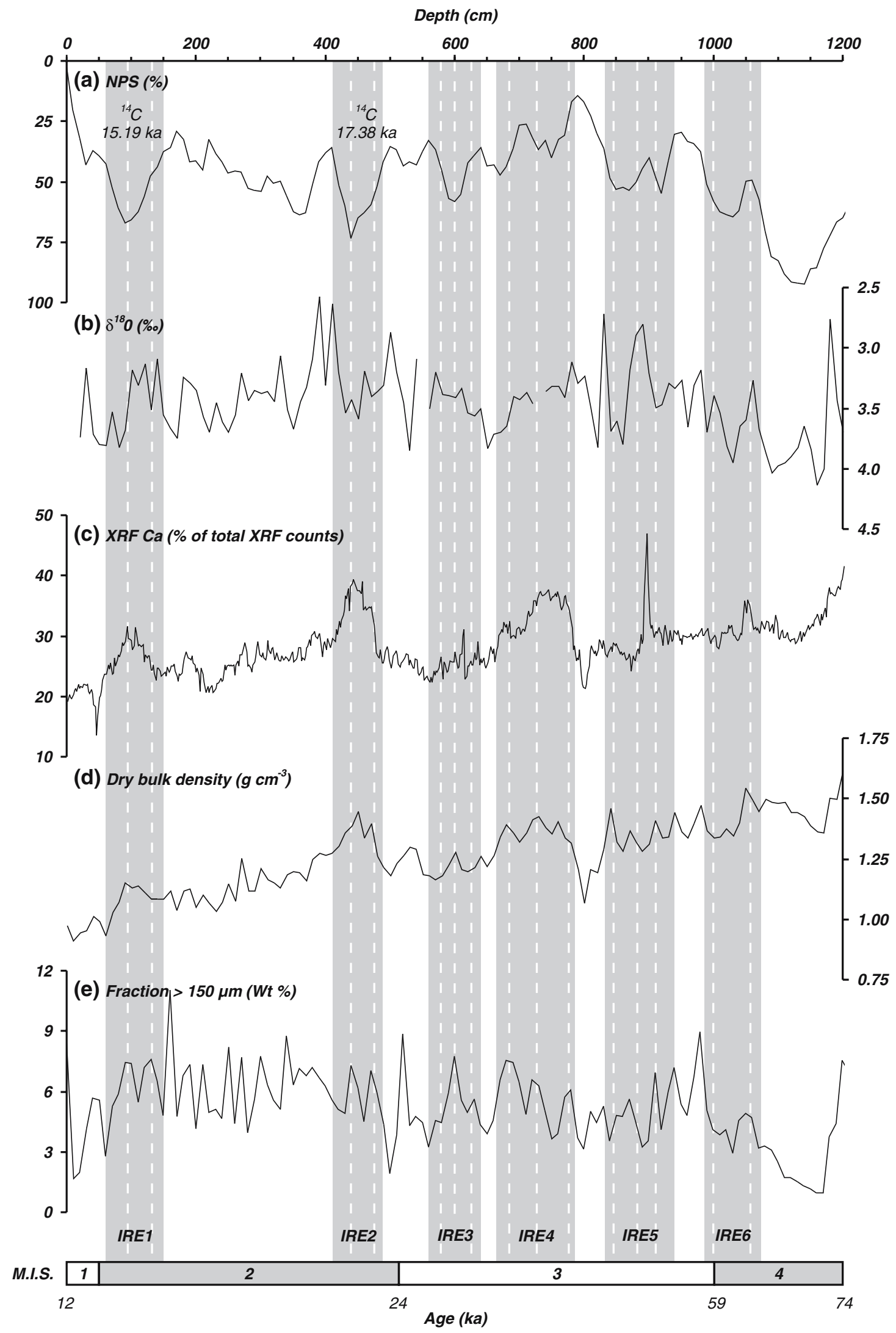

Fig. 9 Detail of the glacial part of core MD99-2327 (Fig. 6), with special attention to the occurrence of the ice-rafting events (greyshaded areas), with a relative abundance the planktonic foraminifera Neogloboquadrina pachyderma s., b $\delta^{18} \mathrm{O}$ stable isotopes (\%o vs.

PDB), c CORTEX XRF Ca values ( $\%$ of the total counts of $\mathrm{Si}, \mathrm{K}, \mathrm{Ca}$, $\mathrm{Ti}, \mathrm{Mn}, \mathrm{Fe}$ and $\mathrm{Sr})$, d dry bulk density $\left(\mathrm{g} \mathrm{cm}^{-3}\right)$ and e fraction $>150 \mu \mathrm{m}(\mathrm{wt} . \%)$ 


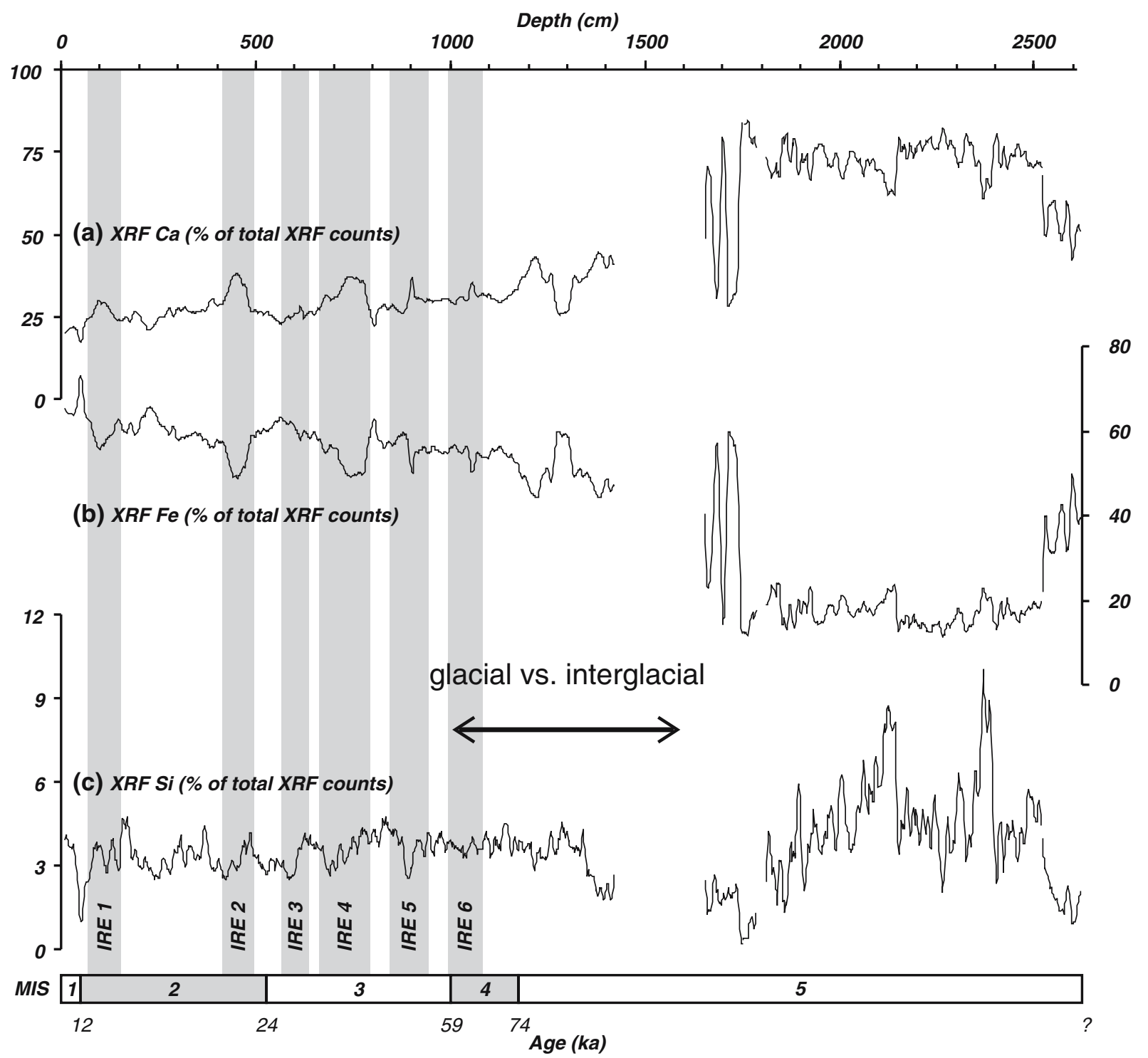

Fig. 10 Five point moving average of the CORTEX XRF Ca (a), $\mathrm{Fe}$ (b) and $\mathrm{Si}$ (c) values in core MD99-2327 as an illustration of the differences between glacial and interglacial conditions. These values

are displayed as the percentage of the total counts of $\mathrm{Si}, \mathrm{K}, \mathrm{Ca}, \mathrm{Ti}$, $\mathrm{Mn}, \mathrm{Fe}$ and $\mathrm{Sr}$

The closer to the BIIS, the MS signal becomes more attenuated, due to the growing influence of ice-rafted debris derived from Irish Palaeozoic carbonate rocks and chalk fragments (Scourse et al. 2000; Richter et al. 2001). The MS record of core MD99-2327 (Fig. 6) is comparable with a core in the Feni drift, described in Richter et al. (2001). The susceptibility signal is fairly weak and only two events are recognised in the glacial part of the core; a high plateau is present from 0 to $200 \mathrm{~cm}$ and a sharp peak is observed at $900 \mathrm{~cm}$ (Fig. 6). The latter also stands out in the X-ray imagery (Fig. 8f).

IRE1 $(70-140 \mathrm{~cm})$ Figure 9 clearly shows a progressive cooling pattern followed by a fast warming-up in the NPS with culmination on $90 \mathrm{~cm}$. Coeval, there is a raise in $\mathrm{Ca}$ in the XRF record, as well in the density and luminosity (Figs. 6,9). There are two elevated IRD levels within this event (90 and $130 \mathrm{~cm}$ ). A general cooler trend is also visible in $\delta^{18} \mathrm{O}$ record. X-ray imagery shows a higher density with several dropstones (Fig. 8a). An AMS ${ }^{14} \mathrm{C}$ date on $90 \mathrm{~cm}$ yields an age of $15.19 \pm 0.13 \mathrm{ka} \mathrm{BP}$, which is consistent with the age of HL1 $(15 \pm 0.7 \mathrm{ka})$ of Elliot et al. (1998), the theory of precursor events of Grousset et al. (2001) and land data of McCabe et al. (1998).

IRE2 (420-480 cm) Neogloboquadrina pachyderma s. shows a clear, gradual cooling record with abrupt culmination at about $440 \mathrm{~cm}$ (Fig. 9). The XRF Ca record shows a "plateau" of elevated values from 430 to $470 \mathrm{~cm}$. Dry bulk density values show an inversed Vshaped pattern with two small peaks, which can be linked with maxima of $F_{150}$ (Fig. 9). These two peaks are also visible on SCOPIX as dark bands with abundant 
dropstones and remarkably less bioturbation (Fig. 8b). Right after this event $\delta^{18} \mathrm{O}$, NPS but also some benthic foraminifera indicate a warmer period (Fig. 9). The main peak of IRE2 has been dated at $17.38 \pm$ $0.14 \mathrm{ka} \mathrm{BP}$, which is rather a young age compared to HL2 (21 ka) of Auffret et al. (2002). On the other hand, this timing of this event fits perfectly with the BIIS Drumlin readvance at about $17 \mathrm{ka}$ (Richter et al. 2001; Bowen et al. 2002) and the major meltwater discharge and ice-sheet disintegration reported at $17.5 \mathrm{ka}$ (McCabe et al. 1998; Knutz et al. 2002).

IRE3 $(560-640 \mathrm{~cm})$ Neogloboquadrina pachyderma $s$. clearly shows a colder assemblage, although there is no increase in XRF Ca (Fig. 9). The $F_{150}$ record shows an increase with one large pulse at $600 \mathrm{~cm}$, preceded $(640 \mathrm{~cm})$ and followed $(570 \mathrm{~cm})$ by a smaller one. Density only shows a subtle peak, but the radiographies clearly show the onset of ice-rafted deposition at $619 \mathrm{~cm}$ (Fig. 8c). Despite the clear environmental change observed in NPS, $\delta^{18} \mathrm{O}$ and XRF Ca do not further discriminate this event. Based on its characteristics, IRE3 is tentatively correlated with the atypical HE3 (26.6 ka), according to Auffret et al. (2002).

IRE4 $(650-800 \mathrm{~cm})$ The main pulse of IRE4 is found on the Ca XRF and NPS record in between 700 and $800 \mathrm{~cm}$, culminating at $730 \mathrm{~cm}$ in the luminosity record (Figs. 6, 9). Bulk density data, however, suggests locating the end of IRE4 at $650 \mathrm{~cm}$. There is a broad increase of density in this depth range, featuring three single peak events, which can be correlated with $F_{150}$ maxima and higher densities on the X-ray imagery (Figs. 8d, e, 9). NPS does show colder assemblages over a very short time, but this is not fully confirmed by $\delta^{18} \mathrm{O}$. The proposed equivalent age of IRE4 is $34.2 \mathrm{ka}$ (Auffret et al. 2002).

IRE5 $(830-930 \mathrm{~cm})$ This IRE displays a very broad NPS maximum, with only one large XRF $\mathrm{Ca}$ and luminosity peak (Figs. 6, 9). This last one is not only observed on the radiographies (Fig. 8f), but also on the MS record (Fig. 6). The dry density record shows an inconsistent pattern, although Fig. 8f clearly shows very coarse ice-rafted sand in a finer, but denser matrix. Immediately after this event, $20 \mathrm{~cm}$ of very fine layering suggests rapid accumulation from turbid plumes due to freshwater input (Auffret et al. 2002). The $\delta^{18} \mathrm{O}$ record does show a significant cooling during this episode. The main peak of IRE5 was tentatively correlated with HL5, dated at $45.5 \mathrm{ka}$ (Auffret et al. 2002).

IRE6 $(980-1,070 \mathrm{~cm})$ Several records as $\delta^{18} \mathrm{O}$ and NPS show a significant cooling in this depth range (Fig. 9). Although the XRF Ca level does not seem to be that high, elevated values are observed on the luminosity data. The density and IRD maxima are offset with several centimetres downcore (earlier in time) with respect to the peak of cold events. X-ray data show faint, dark banded patterns with sparse ice-rafted sand (Fig. 8g). A tentative age for IRE6 is $62.00 \mathrm{ka}$ (Auffret et al. 2002), although the determination of this IRE should be treated with caution.

\section{Sedimentary processes}

\section{Unit II}

Ice-rafted deposits are obviously most dominant in the unit. Particle size analysis show that this unit consists of poorly sorted fine-grained sediments with a significantly high percentage of silt (Fig. 7). Near the base of this unit, however, the sand fraction increases. The mean sortable silt proxy (Fig. 11), which can provide estimates in bottom-current intensity (McCave et al. 1995), reveals short-term variations. Since the inferred MIS4, five intervals of peak currents $(28-33 \mu \mathrm{m})$ and five intervals of lower currents $(22-26 \mu \mathrm{m})$ are observed. These peak current events (PCE) are obviously more long lived when compared to the variations in the fraction $>150 \mu \mathrm{m}$ (Figs. 7, 11). Most of these PCE are accompanied by a sharp rise in the abundance of the benthic foraminifer $U$. mediterannea (Fig. 11), which seems to occur during warmer periods. Schönfeld (2002) and Schönfeld and Zahn (2000) recognised this species among others in the epibenthic group of foraminifers, dwelling in an environment with elevated benthic currents within the core of MOW within the Gulf of Cadiz. Most probably, a comparable environmental association can be found on the slopes of the Porcupine Seabight.

In a way, these five peak current intervals seem to interfinger with the six IRE. Although both processes (PCE vs. IRE) cover the range of silt-sized particles, they can be considered as acting independently from each other. While IRE are culminating during cold events, four of the five PCE are peaking during warm periods (Fig. 11). Only the two most recent PCE are situated closely to an IRE. In this case, current-sorted silt and ice-rafted silt are interfered (Fig. 11).

\section{Units I and III}

Despite a considerable difference in thickness, both units I and III have comparable lithologic and biogenic characteristics. The XRF data of unit III shows noteable differences with unit II; high levels of $\mathrm{Ca}$, low levels of $\mathrm{Fe}$ and significant amounts of Si (Fig. 10). Considerable short-term scatter for all three elements is certainly due to grain-size variability rather than changes in chemical composition. The sand percentage of this part of the core runs up to $95 \%$, containing predominantly quartz grains and (reworked) foraminifera. These sediments are relatively better sorted compared to the overlying units, suggesting a significant benthic current influence (Fig. 7). In this unit, the sortable silt proxy cannot be applied because of the very low silt content, which probably has been winnowed by strong currents. An alternative method to estimate the benthic current 
Depth (cm)

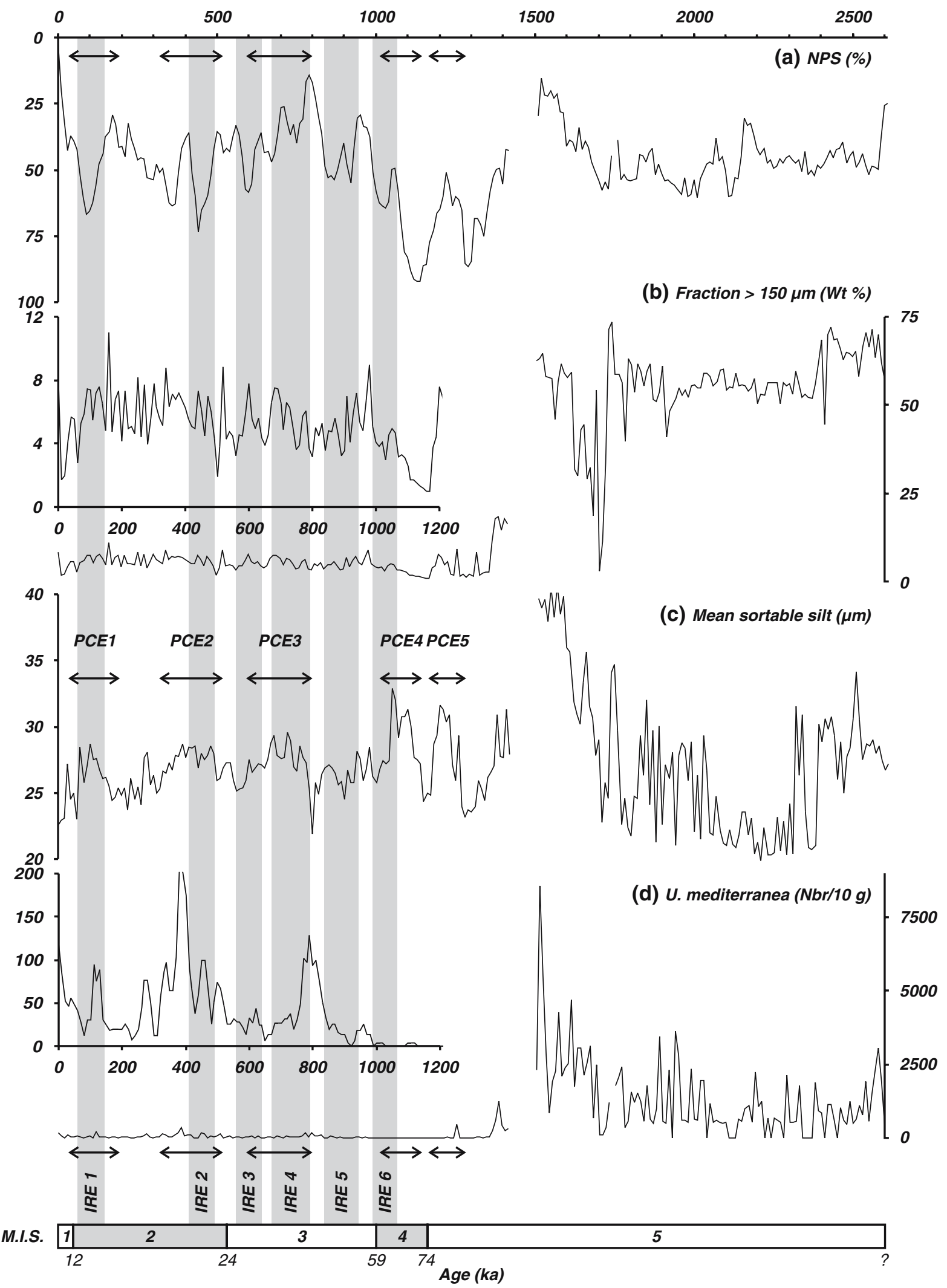

Fig. 11 Sedimentary processes and paleoceanographic interpretation of core MD99-2327 with a relative abundance the planktonic foraminifera Neogloboquadrina pachyderma s., b fraction $>150 \mu \mathrm{m}$ (wt.\%), $\mathbf{c}$ mean sortable silt $(\mu \mathrm{m})$ and $\mathbf{d}$ abundance of the benthic

foraminifer $U$. mediterranea (number per $10 \mathrm{~g}$ ). Within parts $\mathbf{b}$ and d, a zoom of the glacial detail is presented. The six ice-rafting events are indicated by the grey-shaded areas. The range of the peak current events has also been indicated by arrowed lines 
Fig. 12 The a relative abundance the planktonic foraminifera Neogloboquadrina pachyderma $s$. within core MD99-2327 is compared with the b sedimentation rates $\left(\mathrm{cm} \mathrm{ka}^{-1}\right)$ and $\mathbf{c}$ total fluxes $\left(\mathrm{g} \mathrm{cm}^{-2} \mathrm{ka}^{-1}\right.$ ) over the last glacial period. The six icerafting events are indicated by the grey-shaded areas

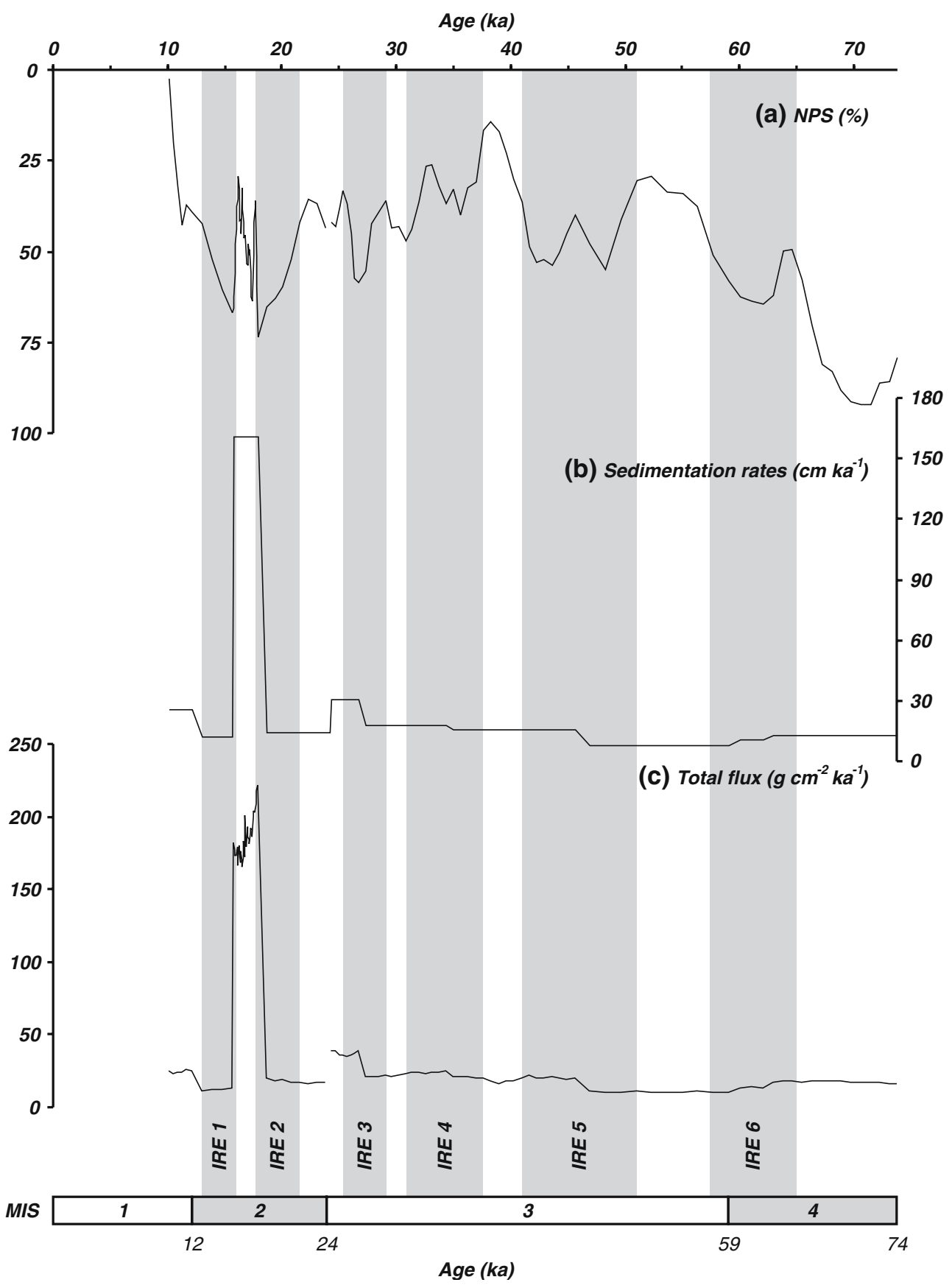

intensity can be provided by the mean of the $63-150-\mu \mathrm{m}$ fraction. This fraction encompasses the majority of the sediment, but excludes grains larger than $150 \mu \mathrm{m}$. Fluctuations in this parameter correspond well with fluctuations in skewness (Fig. 7). As such, increasing currents might be indicated by a coarsening in skewness as the finer components are winnowed away. This trend also corresponds with an increase in the degree of sorting, although mostly a fine tail remains present (Fig. 7f). As such, several fluctuations in current strength can be observed in unit III, with peak currents within the central part. As an exception on the general characteristics of this unit, the two finer-grained layers about
$1,700 \mathrm{~cm}$ would be represented by small intervals of more sluggish currents displaying almost glacial values.

\section{Discussion}

\section{A record of BIIS variability}

The sedimentary record of the glacial part of this core provides a unique insight in the variability of the BIIS. It carries a large and very essential BIIS signature due to its proximity during glacial times. The structure of IRE1, 2, 3 and 4 are similar to the several pulses of 
ice-rafted debris that where observed in typical NE Atlantic HL by Auffret et al. (2002) and Grousset et al. (2001). These HL contain a central Laurentide-sourced peak preceded and followed by a European-sourced event. A comparable threefold structure is recognised in IRE3, 4 and possibly 5. IRE1 and 2 only have a double pulsation, which might imply that during the last $25 \mathrm{ka}$ no Laurentide material reached this site and only the precursor and after-event were recorded. The mineralogical composition of the ice-rafted debris strongly suggests a predominantly BIIS source. This might also be confirmed by the poor MS record, suggesting the absence of LIS-specific ferromagnetic minerals.

Based on the tentative age model (Table 1), sedimentation rates and sedimentary fluxes were estimated (Fig. 12). This allows us to discuss the BIIS variability in the Porcupine Seabight compared to the Celtic margin (Auffret et al. 2002). MIS4 contains a relative minimum of ice-rafted sand (Figs. 6, 9, 10) with moderate to low fluxes (Fig. 12), suggesting a BIIS in a growing stage (Auffret et al. 2002). High variability ice-rafting starts at about $62 \mathrm{ka}$, with the deposition of IRE6. All subsequent influx of terrigenous particles can be attributed to a probably millennial-scaled destabilisation of the BIIS (Fig. 12). During MIS3, all IRE (3-6) are succeeding each other very closely and even continue smoothly one into the other. The slight increase of the sedimentation rates and fluxes at about $45 \mathrm{ka}$ (Fig. 12) illustrates a further expansion of European ice sheets and subsequent supply of detrital material. A small peak observed in the total flux values could be related with a pre-Last Glacial Maximum deglaciation about 25-37 ka which was observed by Bowen et al. (2002).

With the start of MIS2, the sedimentation rates start to increase drastically (Fig. 12). This episode reflects a higher (millennial-scaled?) BIIS destabilisation with more ice-rafted debris discharges than from IRE1 and 2 only. Grousset et al. (2001) already mentioned rapid 1-2 ka cycles by European ice sheets in order to feed the HL precursor and after-events. This also underlines again that BIIS was a long-lived feature that acted as a mobile and sensitive ice sheet (Bowen et al. 2002). The Irish inland ice began a rapid advance after $30 \mathrm{ka}$ with a maximum extent between 24 and $40 \mathrm{ka}$ (Richter et al. 2001). According to Bowen et al. (2002) the final retreat for the BIIS from the shelf occurred at $25 \mathrm{ka}$. Two major shelf edge advances and BIIS collapse were reported from 26 to $18 \mathrm{ka}$ and at 15 ka (Dowling and Coxon 2001; Knutz et al. 2002), fitting the ages of respectively IRE2 and IRE1. Bowen et al. (2002) and McCabe and Clark (1998) even attributed a significant deglaciation of the southern BIIS at about $17.4 \mathrm{ka}$, which could very well explain the $\delta^{18} \mathrm{O}$ meltwater peaks after IRE2. Both IRE are thus regional events, with a rather low global significance and spreading.

A comparable pattern of sedimentary fluxes has been recognised in cores located to the south on Goban Spur and the Celtic margin described by Auffret et al. (2002). The total terrigenous flux is slightly higher compared with core MD95-2002 on Meriadzek Terrace and significantly higher with core NKS12 on Goban Spur. This means that the net sedimentary evolution during the last glacial period along the Irish-Celtic margin has been relatively similar, albeit containing several important differences. First of all, our study site is more proximal in location to the source area whilst the sites of Auffret et al. (2002) are more remote. The Meriadzek Terrace core most likely records variations in sediment supply via the channel river systems coming from a large NW-European drainage area. Secondly, the nature of the IRD also is different. The magnetic signature of our study site is very weak and does not display distinct HL. On the other hand, the cores on the Celtic and Armorican margin do contain a good MS signal (Auffret et al. 2002), although Scourse et al. (2000) recognised a BIIS-sourced HL2 precursor on Goban Spur, which could not be detected by the MS. Cores located in deeper water depths to the centre of the basin and within the Magellan mound province (NW of the study area) do show distinct MS pulses (Foubert et al., this volume). Because of the proximal position of core MD99-2327 to the BIIS, it is plausible to assume only (smaller or less dense?) BIIS iceberg swarms are passing over this site and LIS icebergs could not reach so far. The influence of these European icebergs seems to be restricted to the nearby basins and gradually looses its dominance to the LIS icebergs.

Late quaternary variability of the hydrodynamic environment

Many observations on and around the study area depict a very active hydrodynamic environment during the present day (New et al. 2001; Huvenne et al. 2002; Roberts et al. 2005; White, this volume; Wheeler et al. 2005 , this volume). The boxcore sample on the core site confirms this with the presence of a quartz-rich currentsorted foraminiferal sand. Such a thin surface veneer was also observed on the Hebridean shelf within the Faroe-Shetland channel and was interpreted as a contourite sand sheet (Armishaw et al. 2000; Akhurst et al. 2002). This requires the presence of a relatively strong, semi-permanent benthic current at intermediate depths at a velocity of more than $30 \mathrm{~cm} \mathrm{~s}^{-1}$ (Stow et al. 2002). The measured and inferred bottom-current velocities for the Belgica mound province have an average of $10-20 \mathrm{~cm} \mathrm{~s}^{-1}$ and can be accelerated up to $100 \mathrm{~cm} \mathrm{~s}^{-1}$ or more near steep slopes or narrow passageways. The observed sedimentary structures on side-scan sonar imagery, nearby or away from a mound indeed show such an association (Fig. 3). The required sediment supply zone can be variable with upstream erosion, pirating and winnowing of slope sands (Armishaw et al. 2000). In this case, several sources are probable. First of all, the Gollum channel system, which is located upstream, could be a supply zone of sands during glacial times. These sands could be remobilised during climatic optimums through enhanced currents. Of course, another source can be provided by the BIIS ice-rafted 
sands, which could also be remobilised during periods of enhanced bottom currents.

Many parameters suggest the entire core consists of contourite sediments. Unit II meets many of the conditions of the muddy contourite facies as defined by Stow and Piper (1984), Rebesco and Stow (2001) and Stow et al. (2002), however combined with a strong glaciomarine component. First of all, it is a mainly siliciclastic fine-grained muddy silt. Indications for a mean grain size are given by Stow and Piper (1984) suggesting 5-40 $\mu \mathrm{m}$ as a range for muddy contourites. Also a sand percentage of $10-15 \%$ is inferred, but in this case, a significant part of the sand content is provenant from ice-rafting. Only sporadically, primary structures can be found, but most of the time the core is structureless. $\mathrm{X}$-ray imagery confirms the extensive bioturbation with (sulphide) filaments, planolites and chondrites burrows (Fig. 8).

The large scatter in the oxygen isotope record could mean that (some of the) forams were reworked, in particular in the sandy part. This problem was also recognised by Stow et al. (1986) suggesting that local reworking by bottom currents makes it difficult to provide a precise chronostratigraphy. The nature and characteristics of units I and III are very similar, suggesting they were deposited by the same sedimentary process. The conditions proposed by Armishaw et al. (2000) and also observed in the present-day hydrodynamic environment must thus also have been the same. Most of these sandy contourites are a mixture of a terrigenous and biogenic content with evidence of abrasion and fragmental bioclasts (Faugères and Stow 1993; Stow et al. 2002). A very thick bedded, structureless coarsegrained deposit such as this one is extremely rare in this kind of environment and can, according to Stow and Mayall (2000), be classified as a deep-water massive sand, which is a good deep-water reservoir facies. Mostly these are sandy debris flows, although these sands can originate from various processes. In this case, many parameters point out that the possibility the sediments of unit III are mass-wasting deposits is rather small. The seismic profile through the coring site does not display features characteristic for a large debris flow or turbidite deposit (Fig. 5). The characteristics of unit III meet with the general characteristics of deep-water massive sands, defined by Stow and Johansson (2000). These sediments are poorly to moderately sorted and have a high degree of reworking. Examples of sandy contourites as deep-water massive sands are rare and are found in morphologically and hydrodynamically special environments with fluctuating enhanced currents as near the Gulf of Cadiz and the Sicilian gateway (Stow and Johansson 2000). In general, the size of a sandy contourite or a deep-water massive sand rarely is bigger than $1 \mathrm{~m}$. Within this morphologic and sedimentary context the presence of a 10-m thick sandy contourite is extremely unique and requires further research.

Although no simple global response from climate on bottom-current activity can be found, it is very likely that the switch between the sandy to a muddy contouritic environment is coupled with palaeoclimatologic events. Faugères et al. (1993) already linked a glacial dampened bottom-current regime due to the presence of sea ice, while climate instability means enhanced bottom-current activity. Recent observations of Akhurst et al. (2002) describe the presence of sandy contourites on the Hebrides slope during as well interglacials as interstadials with enhanced current activity. They also recognise the presence of bottomcurrent action during glacial times, but less intense. Since the presence of enhanced currents in the Belgica mound province is highly dependant on the interaction with the MOW (New et al. 2001; De Mol et al. 2002; White, this volume), it is plausible that glacial times seriously weaken the current regime to a muddy contourite sedimentation. The reduced outflow of MOW was then only restricted to the Gulf of Cadiz and did not penetrate any further in the Atlantic Ocean (Schönfeld and Zahn 2000) so the conditions to create enhanced currents were not met. The variability within the glacial contourite, however, is less clear. Most of the PCE are coeval with presumed warmer periods before or after an IRE (Fig. 11). This event is also coupled to a higher abundance of some benthic foraminiferal species like $U$. mediterranea. Within the core, the abundance of this species reaches a maximum during MIS5 and within unit I. Schönfeld (2002) and Schönfeld and Zahn (2000) classify these species under the epibenthic group, which is largely dependant of fast-flowing water within a core of MOW. During a climatic warmer period (interstadial), the sea level could be more elevated, especially after a pan-Atlantic IRE. This could very well encourage an enhanced MOW production which also could reach further into the Atlantic Ocean and create weak pulses of enhanced currents within the Porcupine Seabight.

\section{Consequences for regional sedimentary history}

The sedimentological study of this site confirms that the sediment body located in between the mounds and the steep flank of seismic unit U2 is a confined drift. Moreover, the studied sedimentary facies is influenced by fluctuating current intensities and thus a contourite drift at mid-water range (Stow et al. 2002). The sediment body meets many similarities with well-known contourite drift systems such as a downcurrent elongation, sub-RD and sub-parallel moderate to lowamplitude reflectors with gradual change between seismic facies (Faugères et al. 1999; Rebesco and Stow 2001; Stow et al. 2002). Compared with other known contourite drifts, the confined drift in the Porcupine Seabight is one of the smaller types $\left(30-40 \mathrm{~km}^{2}\right)$. The few other examples of this type of drift are known within small basins (Stow et al. 2002), but still are much larger. The best comparison can be made with the Sumba drift; a smooth asymmetric mound with 
boundary channels and sandy contourites $(15 \mathrm{~km}$ elongation) (Reed et al. 1987). Due to lateral velocity gradients within the Sumba drift, muddy contourites were deposited on the central part and sandy contourites in boundary channels. However, the Sumba confined drift is $15 \mathrm{~km}$ wide, while our equivalent only is $4 \mathrm{~km}$ wide. It could thus very well be possible that lateral facies changes are less pronounced in our small mounded drift and such changes can only be observed in depth (or time). The nature of the bathymetric restrictions that are responsible for the acceleration of deep currents, however are of a completely different nature. Whereas within the Sumba drift and other confined drifts a more tectonically controlled background is present, the interaction between water-mass mixing and bathymetric interaction is steered in this case by a combination of a turbulent sedimentary history with several erosion episodes and current-controlled biogenic build-ups. Within such a dynamic and irregular environment, it is expected that other than contourites also turbiditic and other mass-wasting deposits can be inferred. Within the Belgica mound province, it can be concluded that the presence of this confined contourite drift is a very local feature, bound to several geological, climatological, biological and hydrodynamic variables.

\section{Summary and conclusions}

The Belgica mound province, located on the eastern slope of the Porcupine Seabight can be considered as a unique environment within the North Atlantic domain because of two reasons. First of all, its proximity to the BIIS makes this area the perfect observatory to monitor its variability and its influence on the NE Atlantic palaeoceanography. Secondly, within Pleistocene times the interplay of several environmental factors such morphology, geology, oceanography and hydrodynamics have been responsible for (1) the settling of cold-water coral banks and (2) a variety of special deep-sea sedimentary processes. As many other papers presented in this volume, this study also illustrates the close interaction between these two factors.

The palaeoceanographic record of core MD99-2327 has been largely influenced by the nearby presence of the BIIS. Six IRE were described and can be compared with the North Atlantic Heinrich Events. However, these regional events carry a very strong BIIS signature and only a limited influence of Laurentide icebergs was found. Most of these IRE have been deposited during a two- or three-phase pulses, suggesting millennial-scaled BIIS variability. The abundance of the ice-rafted debris shows a massive BIIS disintegration from $25 \mathrm{ka}$. A comparison with cores on the Celtic margin and in the northern part of the Porcupine Seabight shows a decreasing importance of the BIIS-derived ice-rafted grains and an increase of LIS-derived grains when moving towards more distal position from the Irish mainland.
On top of the influx of ice-rafting material, our data also shows a very important record of a variable lateral sedimentary influx, as well in time as well as in vigour. The studied sedimentary section was located on the eastern flank of a small confined contourite drift. The occurrence and morphology of this drift has been influenced by the special regional setting, more in particular the presence of coral banks and the underlying palaeotopography. Core data and side-scan sonar imagery proves the presence of a sandy contourite sheet with sand waves. This Holocene sandy contourite sheet shares many characteristics with the interglacial part of the core, located between 1,500 and 2,625 cm. During this period, we can infer a similar environmental situation as the one of the present day. This sandy contourite can also be considered as one of the largest known deepwater massive sands.

During the transition from MIS5 to MIS4, the accumulating ice volumes of the pan-Atlantic ice sheets were responsible for a global sea-level drop and the distribution of the MOW in the Eastern Atlantic was seriously hampered. Since the presence of the MOW was vital to the vigorous hydrodynamic environment in the Belgica mound province, the activity of the glacial bottom currents was reduced. However, evidence of current reactivation, coupled with warmer periods and the increase of epibenthic foraminifers, suggests enough MOW sporadically entered the Porcupine Seabight in order to shortly enhance the bottom-current production. This glacial part of the core is a typical muddy contourite with a significant glacio-marine contribution.

Acknowledgments This study was funded through the OMARC EC FP5 GEOMOUND and ECOMOUND projects. We appreciate the efforts made by the captains, crews and shipboard parties of R/V Belgica (1997-2001), R/V Marion Dufresne (1999), R/V Discovery 248 (2000). Core MD99-2327 has been taken within the framework of the IMAGES programme. The IPEV and Yvon Balut are also thanked for the core acquisition and for logistic support. We are very grateful to S. Louwye for the use of the facilities of the UGent palaeontology lab. We also appreciated the discussions with J.-C. Duplessy and L. Labeyrie as well as the use of the LSCE facilities. O. Weber, M. Cremer and J. Saint-Paul (DGO, Université Bordeaux I) are acknowledged for their experience for the SCOPIX analyses. We would also like to thank A. Vaars and S. van der Gaast (NIOZ) for respectively the CORTEX XRF measurements and the discussion of the results. The authors would also like to acknowledge the many helpful and constructive comments of the reviewers J.C. Faugères and J.S. Laberg. DVR is a post-doctoral fellow funded by the FWO-Flanders.

\section{References}

Akhurst MC, Stow DAV, Stoker MS (2002) Late Quaternary glacigenic contourite, debris flow and turbidite process interaction in the Faroe-Shetland Channel, NW European continental margin. In: Stow DAV, Pudsey CJ, Howe JA, Faugères JC, Viana AR (eds) Deep-water contourite systems: modern drifts and ancient series, seismic and sedimentary characteristics. Geological Society memoirs 22, London, pp 73-84

Armishaw JE, Holmes RW, Stow DAV (2000) The Barra Fan: a bottom-current reworked, glacially-fed submarine fans system. Mar Petrol Geol 17:219-238 
Auffret GA, Pujol C, Baltzer A, Bourillet JF, Müller C, Tisot JP (1996) Quaternary sedimentary regime on the Berthois Spur (Bay of Biscay). Geomar Lett 16:76-84

Auffret GA, Zaragosi S, Dennielou B, Cortijo E, Van Rooij D, Grousset FE, Pujol C, Eynaud F, Siegert M (2002) Terrigenous fluxes at the Celtic margin during the last glacial cycle. Mar Geol 188:79-108

Bard E (1998) Geochemical and geophysical implications of the radiocarbon calibration. Geochim Cosmochim Acta 62:20252038

Beyer A, Schenke HW, Klenke M, Niederjasper F (2003) High resolution bathymetry of the eastern slope of the Porcupine Seabight. Mar Geol 198:27-54

Bond G, Lotti R (1995) Iceberg discharges into the North Atlantic on millennial time scales during the last glaciation. Science 267:1005-1010

Bond G, Heinrich H, Broecker WS, Labeyrie LD, McManus J, Andrews JT, Huon S, Jantschik R, Clasen S, Simet C, Tedesco K, Klas M, Bonani G, Ivy S (1992) Evidence for massive discharges of icebergs into the North Atlantic ocean during the last glacial period. Nature 360:245-249

Bowen DQ, Phillips FM, McCabe AM, Knutz PC, Sykes GA (2002) New data for the last glacial maximum in Great Britain and Ireland. Quat Sci Rev 21:89-101

Carter L, McCave IN (1994) Late Quaternary sediment pathways through the deep ocean, east of New Zealand. Paleoceanography 9(6):1061-1085

Chi J, Mienert J (1996) Linking physical property records of Quaternary sediments to Heinrich events. Mar Geol 131:57-73

De Mol B, Van Rensbergen P, Pillen S, Van Herreweghe K, Van Rooij D, McDonnell A, Huvenne V, Ivanov M, Swennen R, Henriet JP (2002) Large deep-water coral banks in the Porcupine Basin, southwest of Ireland. Mar Geol 188:193-231

De Mol B, Henriet JP, Canals M (2005) Development of coral banks in Porcupine Seabight: do they have Mediterranean ancestors? In: Freiwald A, Roberts JM (eds) Cold-water corals and ecosystems. Springer, Berlin Heidelberg New York, pp $515-533$

Dorschel B, Hebbeln D, Rüggeberg A, Dullo WC, Freiwald A (2005) Growth and erosion of a cold-water coral covered carbonate mound in the Northeast Atlantic during the Late Pleistocene and Holocene. Earth Planet Sci Lett 233:33-44

Dorschel B, Hebbeln D, Rüggeberg A, Dullo C (this volume) Carbonate budget of a cold-water coral carbonate mound: Propeller Mound, Porcupine Seabight. Int J Earth Sci

Dowling LA, Coxon P (2001) Current understanding of Pleistocene temperate stages in Ireland. Quat Sci Rev 20:1631-1642

Elliot M, Labeyrie LD, Bond G, Cortijo E, Turon JL, Tisnerat N, Duplessy JC (1998) Millennial-scale iceberg discharges in the Irminger Basin during the last glacial period: relationship with the Heinrich events and environmental settings. Paleoceanography 13(5):433-446

Faugères JC, Stow DAV (1993) Bottom-current-controlled sedimentation: a synthesis of the contourite problem. Sediment Geol 82:287-297

Faugères JC, Mézerais ML, Stow DAV (1993) Contourite drift types and their distribution in the North and South Atlantic Ocean basins. Sediment Geol 82:189-203

Faugères J-C, Stow DAV, Imbert P, Viana AR (1999) Seismic features diagnostic of contourite drifts. Mar Geol 162:1-38

Foubert A, Beck T, Wheeler AJ, Opderbecke J, Grehan A, Klages M, Thiede J, Henriet JP, the Polarstern ARK-XIX/3a shipboard party (2005) New view of the Belgica mounds, Porcupine Seabight, NE Atlantic: preliminary results from the Polarstern ARK-XIX/3a ROV cruise. In: Freiwald A, Roberts JM (eds) Cold-water corals and ecosystems. Springer, Berlin Heidelberg New York pp 403-415

Foubert A, Van Rooij D, Blamart D, Henriet JP (this volume) Linking X-ray imagery and magnetic properties as a proxy of the content of long cores in mound provinces; a case study from the Porcupine Basin. Int J Earth Sci
Grousset FE, Labeyrie LD, Sinko JA, Cremer M, Bond G, Duprat J, Cortijo E, Huon S (1993) Pattern of ice-rafted detritus in the glacial North Atlantic. Paleoceanography 8(2):175-192

Grousset FE, Cortijo E, Huon S, Hervé L, Richter TO, Burdloff D, Duprat J, Weber O (2001) Zooming in on Heinrich layers. Paleoceanography 16(3):240-259

Hargreaves PM (1984) The distribution of Decapoda (Crustacea) in the open ocean and near-bottom over an adjacent slope in the northern North-East Atlantic Ocean during autumn 1979. J Mar Biolog Assoc UK 64:829-857

Holland CH (2001) The geology of Ireland. Dunedin Academic, Edinburgh, p 531

Huthnance JM (1995) Circulation, exchange and water masses at the ocean margin: the role of physical processes at the shelf edge. Prog Oceanogr 35:353-431

Huvenne V, Blondel P, Henriet JP (2002) Textural analyses of sidescan sonar imagery from two mound provinces in the Porcupine Seabight. Mar Geol 189:323-341

Huvenne VAI, Beyer A, de Haas H, Dekindt K, Henriet JP, Kozachenko M, Olu-Le Roy K, Wheeler A, the TOBI/Pelagia 197, CARACOLE cruise participants (2005) The seabed appearance of different coral bank provinces in the Porcupine Seabight, NE Atlantic: results from sidescan sonar and ROV seabed mapping. In: Freiwald A, Roberts JM (eds) Cold-water corals and ecosystems. Springer, Berlin Heidelberg New York, pp. $535-569$

Huvenne VAI, Bailey W, Shannon PM, Naeth J, di Primio R, Henriet JP, Horsfield B, de Haas H, Wheeler AJ, Olu-Le Roy K (this volume) The Magellan mound province in the Porcupine Basin. Int J Earth Sci

Jansen JHF, Van der Gaast SJ, Koster B, Vaars AJ (1998) CORTEX, a shipboard XRF-scanner for element analyses in split sediment cores. Mar Geol 151:143-153

Kassens H, Sarnthein M (1989) A link between paleoceanography, early diagenetic cementation, and shear strength maxima in Late Quaternary deep-sea sediment? Paleoceanography 12:253269

Knutz PC, Austin WEN, Jones EJW (2001) Millennial-scaled depositional cycles related to British Ice Sheet variability and North Atlantic paleocirculation since $45 \mathrm{kyr}$ BP, Barra Fan, UK margin. Paleoceanography 16(1):53-64

Knutz PC, Jones EJW, Austin WEN, van Weering TCE (2002) Glacimarine slope sedimentation, contourite drifts and bottom current pathways on the Barra Fan, UK North Atlantic margin. Mar Geol 188:129-146

Le Bas T, Hühnerbach V (1999) PRISM processing of remotelysensed imagery for seafloor. Mapping operators manual version 31. Southampton Oceanographic Centre, UK

Martinson DG, Pisias NG, Hays JD, Imbrie J, Moore TC, Shackleton NJ (1987) Age dating and the orbital theory of the ice ages: development of a high-resolution 0 to 300,000-year chronostratigraphy. Quat Res 27:1-29

McCabe AM, Clark PU (1998) Ice-Sheet variability around the North Atlantic Ocean during the last deglaciation. Nature 392:373-377

McCabe AM, Knight J, McCarron S (1998) Evidence for Heinrich event 1 in the British Isles. J Quat Sci 13(6):549-568

McCave IN, Manighetti B, Robinson SG (1995) Sortable silt and fine sediment size/composition slicing: parameters for palaeocurrent speed and palaeoceanography. Paleoceanography 10(3):593-610

Mertens K (2002) Ruimtelijke en temporele patronen in paleoproductiviteit van kalkschalig nannoplankton en diatomeeën langs NE-Atlantische continentale randen. M.Sc. thesis, Ghent University, Belgium

Migeon S, Weber O, Faugères JC, Saint-Paul J (1999) SCOPIX: a new X-ray imaging system for core analysis. Geomar Lett 18:251-255

Moore JG, Shannon PM (1992) Palaeocene-Eocene deltaic sedimentation, Porcupine Basin, offshore Ireland-a sequence stratigraphic approach. First Break 10(12):461-469 
Moros M, Kuijpers A, Snowball I, Lassen S, Bäckström D, Gingele F, McManus J (2002) Were glacial iceberg surges in the North Atlantic triggered by climatic warming? Mar Geol 192:393-417

New AL, Barnard S, Herrmann P, Molines JM (2001) On the origin and pathway of the saline inflow to the Nordic Seas: insights from models. Prog Oceanogr 48:255-287

Pingree RD, Le Cann B (1989) Celtic and Armorican slope and shelf residual currents. Prog Oceanogr 23:303-338

Rebesco M, Stow DAV (2001) Seismic expression of contourites and related deposits: a preface. Mar Geophys Res 22(5-6):303308

Reed DL, Meyer AW, Silver EA, Prasetyo H (1987) Contourite sedimentation in an intraoceanic forearc system: eastern Sunda Arc, Indonesia. Mar Geol 76(3-4):223-242

Rice AL, Thurston MH, New AL (1990) Dense aggregations of a hexactinellid sponge, Pheronema carpenteri, in the Porcupine Seabight (northeast Atlantic Ocean), and possible causes. Prog Oceanogr 24:179-196

Rice AL, Billet DSM, Thurston MH, Lampitt RS (1991) The Institute of Oceanographic Sciences Biology programme in the Porcupine Seabight: background and general introduction. J Mar Biol Assoc UK 71:281-310

Richter TO, Lassen S, van Weering TCE, de Haas H (2001) Magnetic susceptibility patterns and provenance of ice-rafted material at Feni Drift, Rockall Trough: implications for the history of the British-Irish ice sheet. Mar Geol 173:37-54

Roberts JM, Peppe OC, Lyndsey AD, Mercer DJ, Thomson WT, Gage JD, Meldrum DT (2005) Monitoring environmental variability around cold-water coral reefs: the use of a benthic photolander and the potential of seafloor observations. In: Freiwald A, Roberts JM (eds) Cold-water corals and ecosystems. Springer, Berlin Heidelberg New York, pp 483-502

Ruddiman WF (1977) Late Quaternary deposition of ice-rafted sand in the subpolar North Atlantic (lat $40^{\circ}$ to $65^{\circ} \mathrm{N}$ ). Geol Soc Am Bull 88:1813-1827

Rüggeberg A, Dorschel B, Dullo WC, Hebbeln D (2005) Sedimentary patterns in the vicinity of a carbonate mound in the Hovland Mound Province, northern Porcupine Seabight. In: Freiwald A, Roberts JM (eds) Cold-water corals and ecosystems. Springer, Berlin Heidelberg New York, pp 87-112

Rüggeberg A, Dullo C, Dorschel B, Hebbeln D (this volume) Environmental changes and growth history of Propeller Mound, Porcupine Seabight: evidence from benthic foraminiferal assemblages. Int $\mathbf{J}$ Earth Sci

Schönfeld J (2002) Recent benthic foraminiferal assemblages in deep high-energy environments from the Gulf of Cadiz (Spain). Mar Micropaleontol 44:141-162

Schönfeld J, Zahn R (2000) Late Glacial to Holocene history of the Mediterranean outflow: evidence from benthic foraminiferal assemblages and stable isotopes at the Portuguese margin. Palaeogeogr Palaeoclimatol Palaeoecol 159:85-111

Scourse JD, Hall IR, McCave IN, Young JR, Sugdon C (2000) The origin of Heinrich layers: evidence from $\mathrm{H} 2$ for European precursor events. Earth Planet Sci Lett 182:187-195
Shannon PM, McDonnell A, Bailey W, Croker PF, Naeth J, di Primio R, Horsfield B (this volume) The geological evolution of the Porcupine and Rockall region, offshore Ireland: the structural template for carbonate mound development. Int J Earth Sci

Skinner LC, McCave IN (2003) Analysis and modelling of gravityand piston coring based on soil mechanics. Mar Geol 199:181204

Snoeckx H, Grousset FE, Revel M, Boelaert A (1999) European contribution of ice-rafted sand to Heinrich layers H3 and H4. Mar Geol 158:197-208

Stow DAV, Johansson M (2000) Deep-water massive sands: nature, origin and hydrocarbon implications. Mar Petrol Geol $17: 145-174$

Stow DAV, Mayall M (2000) Deep-water sedimentary systems: new models for the 21st century. Mar Petrol Geol 17:125-135

Stow DAV, Piper DJW (1984) Deep-water fine-grained sediments: facies models. In: Stow DAV, Piper DJW (eds) Fine grained sediments, deep-water processes and facies. Geological Society special publication 15, London, pp. 611-646

Stow DAV, Faugères JC, Gonthier E (1986) Facies distribution and textural variation in Faro drift contourites: velocity fluctuation and drift growth. Mar Geol 72:71-100

Stow DAV, Faugères JC, Howe JA, Pudsey CJ, Viana AR (2002) Bottom currents, contourites and deep-sea sediment drifts: current state-of-the-art. In: Stow DAV, Pudsey CJ, Howe JA, Faugères JC, Viana AR (eds) Deep-water contourite systems: modern drifts and ancient series, seismic and sedimentary characteristics. Geological Society memoirs 22, London, pp 720

Thouveny N, de Beaulieu JL, Bonifay E, Creer KM, Guiot J, Icole M, Johnsen S, Jouzel J, Reille M, Williams T, Williamson D (1994) Climate variations in Europe over the past $140 \mathrm{kyr}$ deduced from rock magnetism. Nature 371:503-506

Van Rooij D, De Mol B, Huvenne V, Ivanov MK, Henriet JP (2003) Seismic evidence of current-controlled sedimentation in the Belgica mound province, upper Porcupine slope, southwest of Ireland. Mar Geol 195(1-4):31-53

Wheeler AJ, Bett BJ, Billet DSM, Masson DG (2000) Very high resolution side-scan mapping of deep-water coral mounds: surface morphology and processes affecting growth. EOS Trans $81(48)$

Wheeler AJ, Kozachenko M, Beyer A, Foubert A, Huvenne VAI, Klages M, Masson DG, Olu-Le-Roy K, Thiede J (2005) Sedimentary processes and carbonate mounds in the Belgica mound province, Porcupine Seabight, NE Atlantic. In: Freiwald A, Roberts JM (eds) Cold-water corals and ecosystems. Springer, Berlin Heidelberg New York, pp 533-564

Wheeler AJ, Beyer A, Freiwald A, de Haas H, Huvenne VAI, Kozachenko M, Olu-Le Roy K (this volume) Morphology and environment of deep-water coral mounds on the NW European margin. Int J Earth Sci

White $\mathrm{M}$ (this volume) The hydrographic setting for the carbonate mounds of the Porcupine Bank and Sea Bight. Int J Earth Sci 